https://doi.org/10.11646/zootaxa.4433.3.9

http://zoobank.org/urn:lsid:zoobank.org:pub:AD2CD33C-1E75-46C5-9EAF-2A1EC854E6E1

\title{
Luciobarbus lanigarensis and $L$. numidiensis, two new species of barbels from the Mediterranean Sea basin in North Africa (Teostei: Cyprinidae)
}

\author{
AMINA BRAHIMI ${ }^{1,5}$, ROLAND LIBOIS $^{1}$, ARNAUD HENRARD ${ }^{2,3} \&$ JÖRG FREYHOF ${ }^{4}$ \\ ${ }^{I}$ Zoogeography Research Unit, Department of Biology, Ecology and Evolution, University of Liège, Chemin de la vallée 4 (Bât. B22) \\ 4000 Sart Tilman,Belgium.E-mail: minagro005@yahoo.fr; roland.libois@uliege.be \\ ${ }^{2}$ Earth and life Institute, Biodiversity research Center, UCL-17. 07. 04, Bâtiment Carnoy, Croix du Sud, 5, B-1348, Louvain-la-Neuve, \\ Belgium. \\ ${ }^{3}$ Royal Museum for Central Africa, Leuvensesteenweg 13, 3080 Tervuren, Belgium.E-mail: arnaud.henrard@africamuseum.be \\ ${ }^{4}$ Leibniz-Institute of Freshwater Ecology and Inland Fisheries (IGB), Müggelseedamm 310, 12587 Berlin, Germany. \\ E-mail: j.freyhof@igb-berlin.de \\ ${ }^{5}$ Corresponding author. E-mail: minagro005@yahoo.fr
}

\begin{abstract}
Two new species of Luciobarbus are described from the Mediterranean Sea basin in Morocco and Algeria. Their monophyly and phylogenetic placement are resolved by molecular analyses using two mitochondrial markers (cyt b and Dloop). Luciobarbus lanigarensis, new species, from the Tafna River drainage in Algeria and Morocco, is distinguished by having orange fins, a great predorsal length (52-59\% SL) and a very long pectoral fin (79-90\% HL). Luciobarbus numidiensis, new species, from the El-Kébir River drainage in Algeria, is distinguished by having a golden pectoral-fin margin, $43-47+1-3$ lateral line scales and a very long anal-fin (19-23\%).
\end{abstract}

Key words: North Africa, Mediterranean biodiversity hotspot, news species, Morphology, Cytochome b, D-loop control

\section{Introduction}

The diversity of Luciobarbus species occurring in the Mediterranean biodiversity hotspot in North Africa has recently received considerable attention. Geiger et al. (2014) presented a comprehensive set of molecular data and treated L. leptopogon as a valid species. Casal-Lopez et al. (2015) described the long-known but unnamed species from northern-most Morocco as L. rifensis. Doadrio et al. (2016b) described the species until then known as $L$. nasus from the Moulouya River drainage as L. guercifensis. Doadrio et al. (2016a) stated that $L$. moulouyensis from the Moulouya River drainage is a synonym of Carasobarbus fritschii and described the Luciobarbus previoulsly known as L. moulouyensis as L. yahyaouii. Finally, Brahimi et al. (2017) presented an identification key of all Luciobarbus species found in the African Mediterranean Sea basin, a new set of molecular data and described two additional new species from Algeria (L. chelifensis \& L. mascarensis).

These studies increased remarkably the number of Luciobarbus species known from the African Mediterranean Sea basin from four (L. callensis, L. nasus, L. moulouyensis, L. setivimensis) to eight. However, there are still several small- and medium-sized rivers flowing to the African Mediterranean Sea inhabited by unstudied populations of Luciobarbus. Here, we provide the description of two additional new species from those rivers, which had passed unnoticed in previous studies.

\section{Material and methods}

Morphology. Fish were caught with hand nets and by electrofishing. After anaesthesia, fishes were either fixed in $5 \%$ formaldehyde and stored in $70 \%$ ethanol or directly fixed in $99 \%$ ethanol. Measurements were made point-to- 
point, with a dial caliper and recorded to $0.1 \mathrm{~mm}$. Two measurements were taken over projections to the body axis: pre-dorsal length and pre-pelvic length. Other methods for measurements and all counts follow Kottelat \& Freyhof (2007). Standard length (SL) is measured from the tip of the snout to the posterior extremity of the hypural complex. The length of the caudal peduncle is measured from behind the base of the last anal-fin ray to the posterior extremitiy of the hypural complex, at mid-height of the caudal-fin base. The length of anal-fin is given together for males and females, as it was not found to be sexually dimorphic. The first unbranched dorsal and analfins rays are hidden in the skin and unbranched rays were counted from X-ray pictures. The position of the dorsalfin origin was determined from $\mathrm{x}$-ray pictures. The last two branched rays articulating on a single pterygiophore in the dorsal and anal fins are counted as "11/2". Scales in lateral series are counted along the midlateral line from the first one to touch the shoulder girdle to the last scale at the posterior extremity of the hypural complex. The scales on the caudal-fin base are separated by + . The holotype is included in the calculation of ranges, means and SD.

Abbreviations used. BI, bayesian inference; cyt $b$, cytochome b; d, cyt b genetic distance; D-loop, displacement loop; HL, lateral head length; ML, maximum likehood analysis; SL, standard length.

Collection codes. FSJF, Fischsammlung J. Freyhof, Berlin; RMCA, Royal Museum for Central Africa, Tervuren; ZFMK, Zoologisches Forschungsmuseum A. Koenig, Bonn.

Molecular analysis. To evaluate the phylogenetic relationships between the Luciobarbus species from the African Mediterranean Sea basin, we were able to generate 42 new mitochondrial sequences (cyt b and D-loop) for three Luciobarbus species (L. guercifensis, L. lanigarensis and L. numidiensis). From NCBI Genbank, 103 additional cyt b sequences and 48 D-loop sequences from Luciobarbus from the African Mediterranean Sea basin were downloaded. Barbus barbus was used as outgroup (Table 1). Polymerase chain reaction (PCR) amplification and sequencing were applied to two fragments of the mitochondrial genome: cytochrome b (cyt b) and D-loop control region. We used GLUDG.L (Palumbi 1996) and H16460 primers (Perdices \& Doadrio 2001) to amplify cyt b, while the D-loop was amplified using L15923 (Iguchi et al. 1997) and H16500 primers (Nishida et al. 1998). All sequences were visualized and edited in SEQUENCHER v.5.2.4 (Gene Codes, USA) and then compared with other GenBank sequences in order to identify any undesirable contamination. The sequences were then aligned using MAFFT v.7 (Katoh \& Standley 2013) with default parameters. Alignment refinement was performed using Gblocks v.0.90b available on the Gblocks Server in order to eliminate poorly aligned positions and divergent regions (Talavera \& Castresana 2007). A combined Cyt b-D-loop alignment was created with seaview v.4.5.4 (Gouy et al. 2010) by concatenating the MAFFT-Gblocks curated alignments of the two markers into a single matrix. For the analyses, datasets were partitioned to account for the differences in evolutionary dynamics among sites and genes. The protein-coding gene ( $\mathrm{Cyt} b$ ) was partitioned into single codon positions. By consequence the combined alignment dataset was subdivided into four partitions: the 1st, 2nd and 3rd codon positions of the cyt $b$ and the D-loop. Both markers and the concatenated alignments were analysed in PartitionFinder v.2 (Lanfear et al. 2017) in order to select the best models per partitions: K80+I (Kimura 1980), F81 (Felsenstein 1981), GTR $+\mathrm{G}$ (Lanave et al. 1984; Tavare 1986; Rodriguez et al. 1990) and HKY +G (Hasegawa et al. 1985) for cyt b 1st, 2nd and 3rd codons positions and D-loop, respectively.

Phylogenetic analyses were inferred using statistical approaches (ML and BI). The phylogenetic analyses were inferred from each marker independently: Cyt b (1140 bp) and D-loop (470 bp) and on the combined alignment (with a total of 1610 sites). Maximum likelihood analyses (ML) (Felsenstein 1981) were implemented in GARLI v.2.1 (Bazinet et al. 2014) using the models suggested by PartitionFinder. In total, 1000 bootstraps (BT) were obtained in four independent runs, each including 250 repetitions. BT values were then summarized on the best maximum likelihood tree using SumTree (Sukumaran \& Holder 2015) (run on DendroPy v.4.0.0; Sukumaran \& Holder 2010). Bayesian inference (BI), was implemented in the Mr.Bayes program v.3.2.5 (Ronquist et al. 2012), using four runs of Metropolis-coupled Markov Chain Monte Carlo (MCMC) sampling and with default model parameters as starting values. The analysis was proceeded up to 10000000 generations, checking that the standard deviation of split frequencies decreased below 0.01 . Best-fit models were applied to each partition. The trees were first edited using Figtree v.1.4.2 (Rambaut 2009) then drawn with Inkscape v.0.91 (http://inkscape.org) for publication. The average uncorrected p-distances among Luciobarbus species from the African Mediterranean Sea basin were calculated for the cyt b gene using MEGA v.6.0 (Tamura et al. 2013). 
TABLE 1. Sequences from GenBank used in this study. Species, localities, the number of sequenced specimens and GenBank accession numbers (cyt b) are given.

\begin{tabular}{|c|c|c|c|}
\hline Species & Locality & Coordinates & GenBank Nr. \\
\hline Luciobarbus biscarensis & Illizi, Algeria & & AY004724 \\
\hline Luciobarbus biscarensis & El-Abiod River, Biskra, Algeria & $35.867736^{\circ} \mathrm{N}, 5.926079^{\circ} \mathrm{E}(42)$ & AY004726 \\
\hline Luciobarbus biscarensis & El-Abiod River, Biskra, Algeria & $35.052039^{\circ} \mathrm{N}, 6.166728^{\circ} \mathrm{E}(43)$ & KY828015 \\
\hline Luciobarbus biscarensis & Foum-El-Gherza reservoir, Biskra, Algeria & $34.870207^{\circ} \mathrm{N}, 5.925388^{\circ} \mathrm{E}(44)$ & KY828009-11 \\
\hline Luciobarbus biscarensis & Loutaya River at Manbae, Biskra, Algeria & $35.094477^{\circ} \mathrm{N}, 5.586152^{\circ} \mathrm{E}(45)$ & KY828012-14 \\
\hline Luciobarbus biscarensis & Ksob River, M'sila, Algeria & $35.840216^{\circ} \mathrm{N}, 4.572089^{\circ} \mathrm{E}(46)$ & KY828019-21 \\
\hline Luciobarbus biscarensis & El-Arab River, Khenchela, Algeria & $35.166192^{\circ} \mathrm{N}, 7.020921^{\circ} \mathrm{E}(41)$ & KY828016-18 \\
\hline Luciobarbus callensis & Abid River, Cap Bon, Tunisia & $36.867286^{\circ} \mathrm{N}, 10.724574^{\circ} \mathrm{E}(2)$ & AY004878 \\
\hline Luciobarbus callensis & Sarrath River, Djerissa, Tunisia & $35.807531^{\circ} \mathrm{N}, 8.563658^{\circ} \mathrm{E}(4)$ & AY004732 \\
\hline Luciobarbus callensis & Ain Assel reservoir, El-Taref, Algeria & $36.747037^{\circ} \mathrm{N}, 8.400955^{\circ} \mathrm{E}(7)$ & AF045974 \\
\hline Luciobarbus callensis & Bou-Namoussa River, El-Taref, Algeria & $36.621504^{\circ} \mathrm{N}, 8.057990^{\circ} \mathrm{E}(8)$ & KY828028-29 \\
\hline Luciobarbus callensis & Bouhamdane River, Guelma, Algeria & $36.468478^{\circ} \mathrm{N}, 7.229560^{\circ} \mathrm{E}(9)$ & KY828022-27 \\
\hline Luciobarbus chelifensis & Rhiou River, Relizane, Algeria & $36.009889^{\circ} \mathrm{N}, 0.992520^{\circ} \mathrm{E}(23)$ & KY828044-46 \\
\hline Luciobarbus chelifensis & Gagar reservoir, Relizane, Algeria & $35.908391^{\circ} \mathrm{N}, 1.008624^{\circ} \mathrm{E}(24)$ & $\begin{array}{l}\text { KY } 828047 \\
\text { KY } 828051\end{array}$ \\
\hline Luciobarbus chelifensis & Sly River, Chelif, Algeria & $36.026609^{\circ} \mathrm{N}, 1.266014^{\circ} \mathrm{E}(22)$ & KY828049-50 \\
\hline Luciobarbus chelifensis & Ghrib reservoir, Ain Defla, Algeria & $36.140553^{\circ} \mathrm{N}, 2.563226^{\circ} \mathrm{E}(21)$ & KY828048 \\
\hline Luciobarbus guercifensis & Melloul River, Guercif, Morocco & $34.218000^{\circ} \mathrm{N}, 3.346700^{\circ} \mathrm{W}$ & $\begin{array}{l}\text { KU257527 } \\
\text { KX681691-93 } \\
\text { KX681695-96 }\end{array}$ \\
\hline Luciobarbus guercifensis & Moulouya River, Ghafoula, Morocco & $34.145000^{\circ} \mathrm{N}, 3.388000^{\circ} \mathrm{W}$ & $\begin{array}{l}\text { KU257525-26 } \\
\text { KU257528 } \\
\text { KX681697 }\end{array}$ \\
\hline Luciobarbus leptopogon & Keddara reservoir, Boumrdèse, Algeria & $36.647275^{\circ} \mathrm{N}, 3.424412^{\circ} \mathrm{E}(18)$ & AF145931 \\
\hline Luciobarbus leptopogon & Chiffa River, Blida, Algeria & $36.445279^{\circ} \mathrm{N}, 2.756340^{\circ} \mathrm{E}(19)$ & AY004749 \\
\hline Luciobarbus leptopogon & Hammam Melouane River, Blida, Algeria & $36.482900^{\circ} \mathrm{N}, 3.041400^{\circ} \mathrm{E}(20)$ & KY828003-08 \\
\hline Luciobarbus mascarensis & Tifrit River, Balloul, Algeria & $34.987064^{\circ} \mathrm{N}, 0.408772^{\circ} \mathrm{E}(25)$ & AY004743 \\
\hline Luciobarbus mascarensis & Taria River, Mascara, Algeria & $35.109848^{\circ} \mathrm{N}, 0.067300^{\circ} \mathrm{E}(26)$ & KY828030-43 \\
\hline Luciobarbus rifensis & Laou River, Chefchaouen, Morocco & & AY004731 \\
\hline Luciobarbus rifensis & Laou River, Derdara, Morocco & $35.118986^{\circ} \mathrm{N}, 5.288900^{\circ} \mathrm{W}(37)$ & КТ003926-30 \\
\hline Luciobarbus rifensis & Hachef River, Dar Chaoui, Morocco & $35.526763^{\circ} \mathrm{N}, 5.713771^{\circ} \mathrm{W}(33)$ & КТ003931-35 \\
\hline Luciobarbus rifensis & Loukos River, Souk Had Laghdir, Morocco & $35.026240^{\circ} \mathrm{N}, 5.404660^{\circ} \mathrm{W}(38)$ & KT003936-40 \\
\hline Luciobarbus setivimensis & Soummam River, Algeria & $36.632246^{\circ} \mathrm{N}, 4.74745^{\circ} \mathrm{E}(16)$ & AY004748 \\
\hline Luciobarbus setivimensis & Aissi River, Tizi Ouzou, Algeria & $36.668968^{\circ} \mathrm{N}, 4.124125^{\circ} \mathrm{E}(17)$ & AY015991-92 \\
\hline Luciobarbus setivimensis & $\begin{array}{l}\text { Ain Zada Reservoir, Bordj-Bou-Arreridj, } \\
\text { Algeria }\end{array}$ & $36.668968^{\circ} \mathrm{N}, 4.124125^{\circ} \mathrm{E}(13)$ & $\begin{array}{l}\text { KY828052- } \\
54\end{array}$ \\
\hline Luciobarbus yahyaouii & Moulouya River, Boumia, Morocco & $32.801789^{\circ} \mathrm{N}, 4.791778^{\circ} \mathrm{W}(31)$ & AY004742 \\
\hline Luciobarbus yahyaouii & Moulouya River, Morocco & $34.226706^{\circ} \mathrm{N}, 2.392343^{\circ} \mathrm{W}(30)$ & AF 145925 \\
\hline Luciobarbus yahyaouii & Moulouya River, Ghafoula, Morocco & $34.145000^{\circ} \mathrm{N}, 3.388000^{\circ} \mathrm{W}$ & KX681704-06 \\
\hline Luciobarbus yahyaouii & Melloul River, Guercif, Morocco & $34.218000^{\circ} \mathrm{N}, 3.346700^{\circ} \mathrm{W}$ & KX681701-03 \\
\hline Luciobarbus yahyaouii & $\begin{array}{l}\text { Zobzite River, Moulouya Basin, Berkine, } \\
\text { Morocco }\end{array}$ & & KX681698-99 \\
\hline Luciobarbus yahyaouii & El Barred River at Asrire, Morocco & & $\begin{array}{l}\text { KY457947-48 } \\
\text { KY457950 }\end{array}$ \\
\hline Barbus barbus & Danube River, Austria & & AB238965 \\
\hline
\end{tabular}




\section{Results}

Phylogenetic inferences (ML and BI) were carried out on each alignment including GenBank sequences and support values from the different analyses are summarized here on the majority rule consensus ML tree obtained from the combined alignment (Fig. 1). The tree topologies obtained from both BI and ML did not differ in the clades recovered, but it differed in the support values for the recovered groups with, in general, BI provided higher support values than the ML analysis.

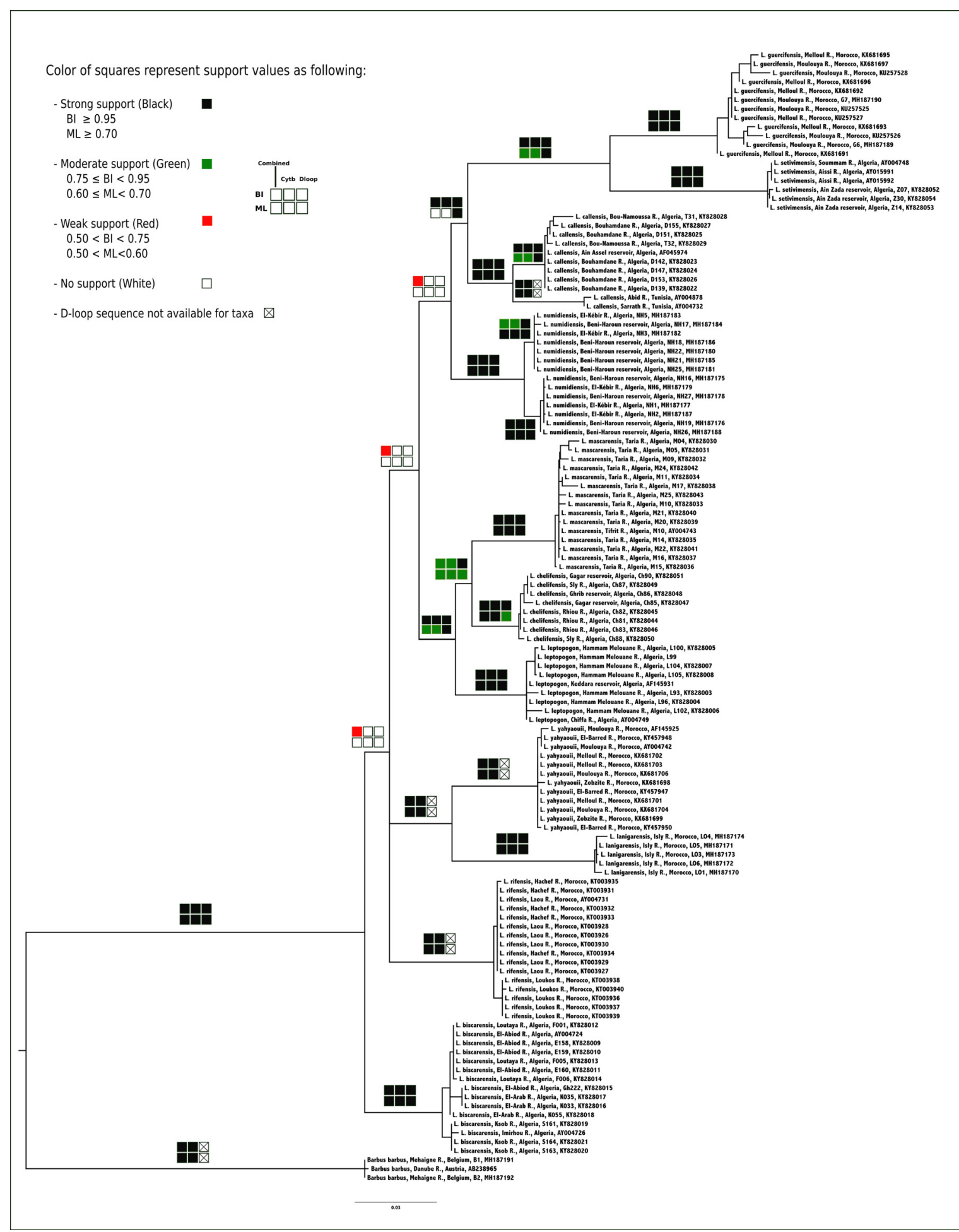

FIGURE 1. Phylogenetic relationships from DNAmt (Cyt b and D-loop) of Luciobarbus species from the African Mediterranean Sea basin, using Bayesian inference (BI) and Maximum Likelihood (ML). Support values from the different analyses run on the combined alignment and on each marker are summarized here on the majority rule consensus. 


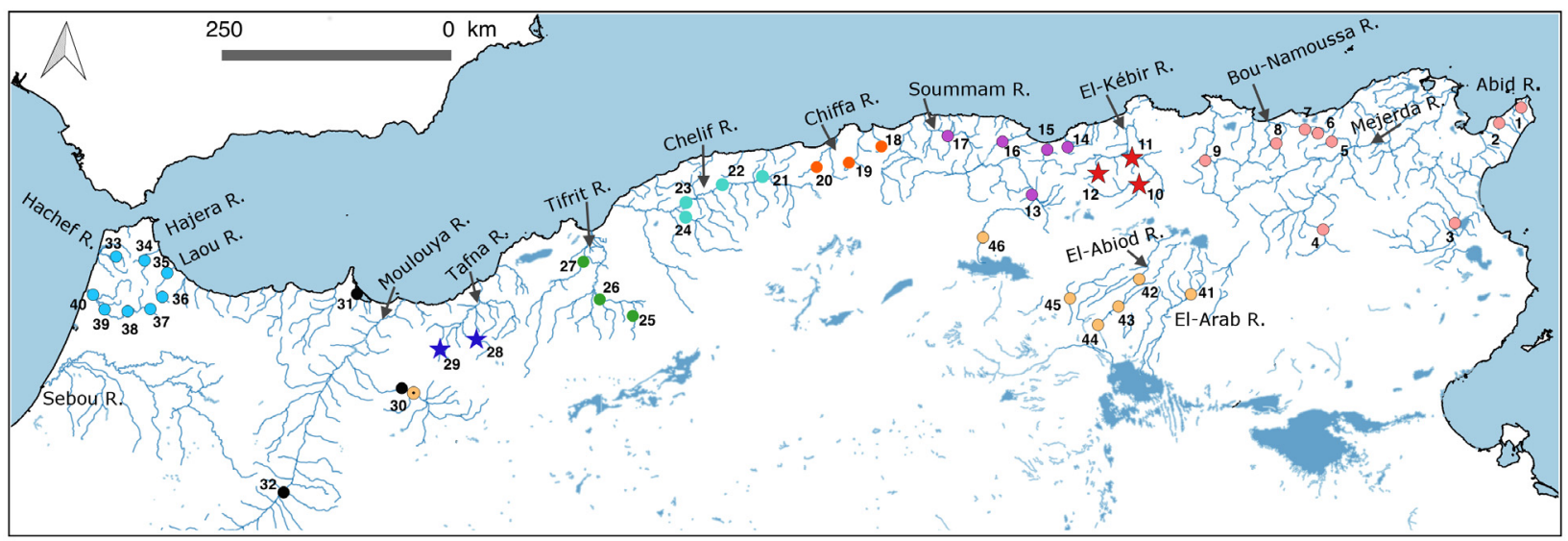

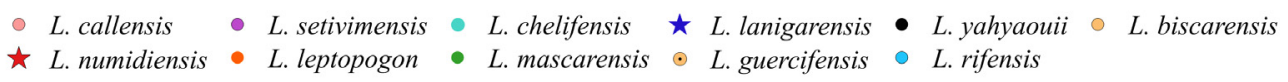

FIGURE 2. Records of Luciobarbus species examined in this study. Numbers correspond to materials examined.

Cyt b and D-loop analyses aslo showed generally similar topologies, congruent with the combined analyses. Indeed, all clades corresponding to species were recovered with high support values in all analyses. Only deeper nodes were not supported, except the monophyly of Luciobarbus. Some species groups are however well supported. Among African Mediterranean Luciobarbus, L. setivimensis, and L. guercifensis are sister group and showed a hight genetic divergence compared to all the others taxa analyzed from this area.

Our analyses also reveal that $L$. mascarensis, L. chelifensis and L. leptopogon form a well-supported Algerian group. Luciobarbus callensis is basal to the clade formed by the two species L. setivimensis and L. guercifensis but is mainly supported by D-loop. It is also the case for L. yahyaouii and L. lanigarensis, but for which mainly the cyt $\mathrm{b}$ gives support to the clade. The genetic distance ( $\mathrm{Cyt} \mathrm{b}$ ) between L. lanigarensis and L. yahyaouii is relatively large $(\mathrm{d}=4.6 \%)$. Individuals of $L$. numidiensis included in the molecular analysis form one well-supported monophyletic clade. This clade is futher separated into two well supported sub-groups, which are however faintly genetically differentiated $(\mathrm{d}=0.28 \%)$, indicating a restriced gene-flow between the populations. The relationships of and affinities between Luciobarbus species of African Mediterranean Sea basin remain unclear.

\section{Key to species of Luciobarbus in the African Mediterranean Sea basin}

The key is developed based on materials examined listed at the end of the text.

1a Barbels thick, rostral-barbel origin close to tip of snout. $\ldots \ldots \ldots \ldots \ldots \ldots \ldots \ldots \ldots \ldots \ldots \ldots \ldots$. $\ldots \ldots$ guercifensis

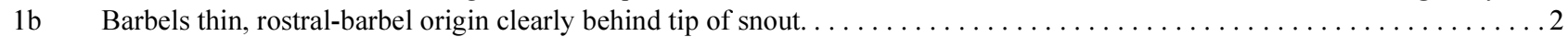

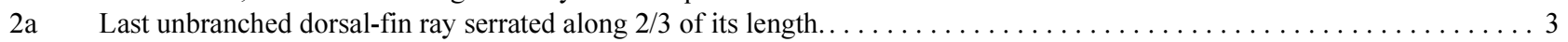

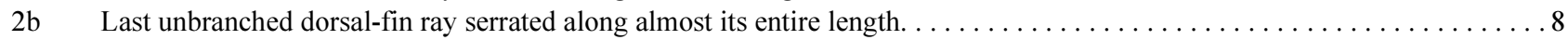

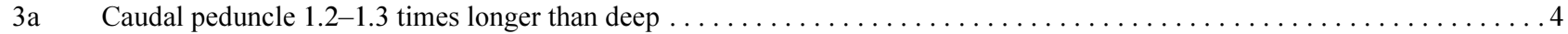

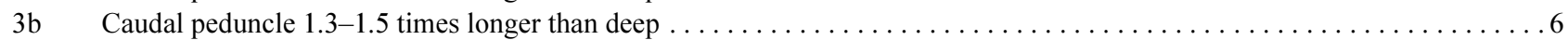

4a Predorsal length 46-52\% SL; interorbital distance 40-44\% HL; 43-47+1-3 lateral line scales . . . . .Luciobarbus setivimensis

4b Predorsal length 52-59\% SL; interorbital distance 36-46\% HL; 41-45+1-3 lateral line scales . . . . . . . . . . . . . . 5

5a Pectoral-fin length $17-21 \%$ SL, 60-79\% HL; usually $41+1-2$ lateral line scales . . . . . . . . . . . . Luciobarbus mascarensis

5b Pectoral-fin length 21-24\% SL, 79-90\% HL; 43-45+1-3 lateral line scales . . . . . . . . . . . Luciobarbus lanigarensis

6a Caudal peduncle depth $13-14 \%$ SL; $43-47+1-2$ lateral line scales . . . . . . . . . . . . . . . . Luciobarbus numidiensis

$6 \mathrm{~b} \quad$ Caudal peduncle depth $10-13 \% \mathrm{SL} ; 41-45+1-2$ lateral line scales $\ldots \ldots \ldots \ldots \ldots \ldots \ldots \ldots \ldots \ldots \ldots$

$7 \mathrm{a}$ Predorsal length 46-52\% SL; Interorbital distance 36-39\% HL; 41-43+1-2 lateral line scales; 4 unbranched dorsal-fin rays. .

Luciobarbus leptopogon Predorsal length $52-56 \%$ SL; Interorbital distance $33-40 \%$ HL; 42-45+1-2 lateral line scales; usually 5 , very rarely 4

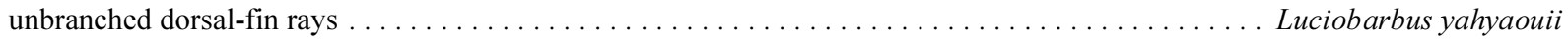

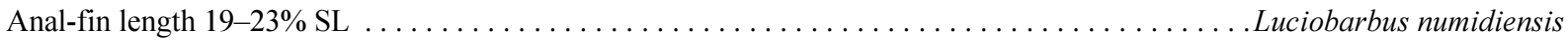

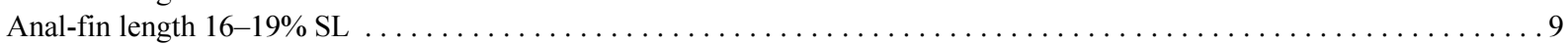
Anal-fin base length $8-10 \%$ SL; $41-43+1-2$ lateral line scales. . . . . . . . . . . . . . . . . Luciobarbus chelifensis Anal-fin base length $6-8 \%$ SL; 43-47+1-3 lateral line scales . . . . . . . . . . Luciobarbus callensis / Luciobarbus rifensis 


\section{Luciobarbus lanigarensis, new species}

(Figs. 3-5)

Holotype. RMCA 2017-022-P-0024, $134 \mathrm{~mm}$ SL; Morocco: Guenfouda prov.: Oued Isly, $34.5118^{\circ} \mathrm{N}, 2.05826^{\circ} \mathrm{W}$. Paratypes. RMCA 2017-022-P-0019-0042, 21, 71-150 mm SL; ZFMK ICH-105602-105603, 2, 115-123 mm SL; same data as holotype.

Material for molecular analyses. RMCA DNA-2017-022-P-LO1-LO6; same data as holotype (GenBank accession numbers: Cyt b: MH187170, MH187171, MH187172, MH187173, MH187174; D-loop: MH187193, MH187194, MH187195, MH187196, MH187197).

Diagnosis. Luciobarbus lanigarensis is distinguished from other Luciobarbus species from the African Mediterranean Sea basin by a combination of characters, none of them unique. Luciobarbus lanigarensis is distributed adjacent to L. mascarensis in the east and L. yahyaouii and L. guercifensis in the west.

It is distinguished from L. guercifensis by having thin barbels (vs. thick), the rostral-barbel origin placed clearly behind the tip of the snout (vs. rostral-barbel origin at the extreme anterior of the snout) and from $L$. mascarensis, $L$. yahyaouii and L. leptopogon, by having a wider interorbital distance (38-47\% HL vs. 36-40 in $L$. mascarensis, 33-40 in L. yahyaouii, 36-39 in L. leptopogon) and a longer pectoral-fin (21-24\% SL vs. 16-21 in $L$. mascarensis, 18-21 in L. yahyaouii). It is further distinguished from $L$. chelifensis, L. leptopogon and $L$. mascarensis by having 43-45+1-3 lateral line scales (vs. 41-43+1-2 in L. chelifensis and L. leptopogon, usually 41+1-2 in L. mascarensis) (Table 8).

TABLE 2. Morphometric data of Luciobarbus lanigarensis (holotype RMCA 2017-022-P-0024; paratypes RMCA 2017-022-P-0019-0042, n=21; ZFMK ICH-105602-105603, n=2; non-preserved individuals, $n=23$ ). The holotype and paratypes are included in the calculation of ranges, means and SD.

\begin{tabular}{|c|c|c|c|c|}
\hline & \multirow[t]{2}{*}{ holotype } & \multicolumn{3}{|c|}{ holotype \& paratypes } \\
\hline & & 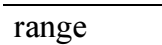 & mean & SD \\
\hline Standard length $(\mathrm{mm})$ & 134 & $71-150$ & & \\
\hline \multicolumn{5}{|l|}{ In percent of standard length } \\
\hline Body depth at dorsal-fin origin & 24.2 & $24.2-29.6$ & 26.4 & 1.6 \\
\hline Head length & 26.2 & $25.5-29.0$ & 27.1 & 1.1 \\
\hline Pre-dorsal length & 53.7 & $53.6-59.2$ & 56.1 & 1.7 \\
\hline Pre-pelvic length & 55.2 & $55.2-60.6$ & 57.7 & 1.4 \\
\hline Pre-anal length & 78.4 & $76.3-84.5$ & 79.5 & 2.1 \\
\hline Dorsal fin base length & 13.8 & $13.5-16.0$ & 14.7 & 0.7 \\
\hline Anal fin base length & 7.4 & $6.6-8.8$ & 7.7 & 0.6 \\
\hline Anal fin length & 21.5 & $20.2-23.0$ & 21.5 & 0.8 \\
\hline Pelvic fin length & 18.3 & $17.0-20.4$ & 18.7 & 1.0 \\
\hline Pectoral fin length & 21.3 & $21.3-23.9$ & 22.4 & 0.7 \\
\hline Caudal peduncle length & 17.4 & $15.4-18.8$ & 17.4 & 0.9 \\
\hline Caudal peduncle depth & 13.1 & $12.1-13.7$ & 12.9 & 0.5 \\
\hline Distance between dorsal and anal-fin origins & 31.6 & $30.3-35.4$ & 33.0 & 1.3 \\
\hline Distance between pectoral and pelvic-fin origins & 28.2 & $27.6-31.9$ & 29.6 & 1.3 \\
\hline Distance between pelvic and anal-fin origins & 24.6 & $21.1-24.6$ & 22.8 & 1,1 \\
\hline \multicolumn{5}{|l|}{ In percent of head length } \\
\hline Snout length & 32 & $29-37$ & 33.2 & 2.2 \\
\hline Eye diameter & 19 & $19-26$ & 21.9 & 2.1 \\
\hline Post-orbital length & 48 & $42-49$ & 44.9 & 1.8 \\
\hline Interorbital distance & 43 & $38-46$ & 41.5 & 2.7 \\
\hline Pectoral-fin length & 81 & 79-89 & 83.0 & 2.7 \\
\hline Caudal peduncle depth & 50 & $43-51$ & 47.8 & 2.4 \\
\hline
\end{tabular}




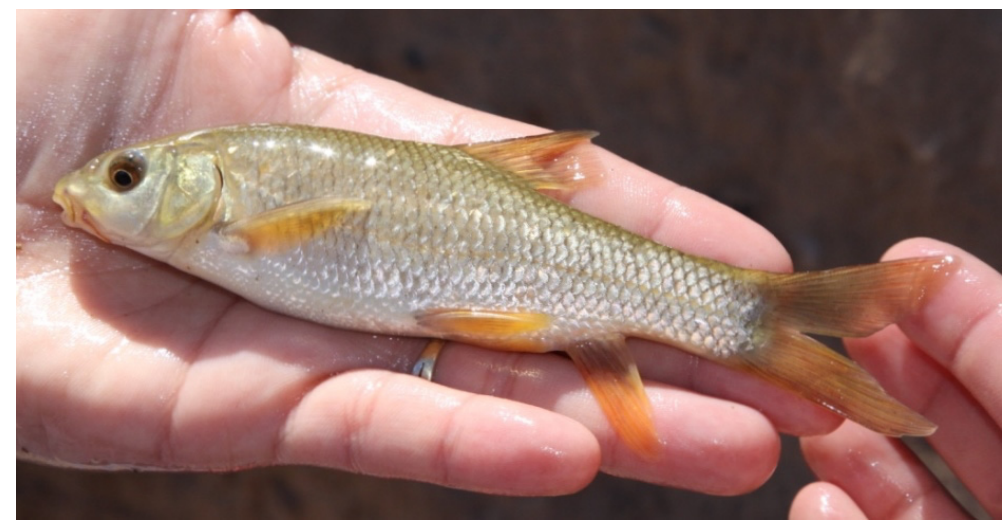

FIGURE 3. Luciobarbus lanigarensis, RMCA 2017-022-P-0020, paratype, 102 mm SL; Morocco: Oued Isly.
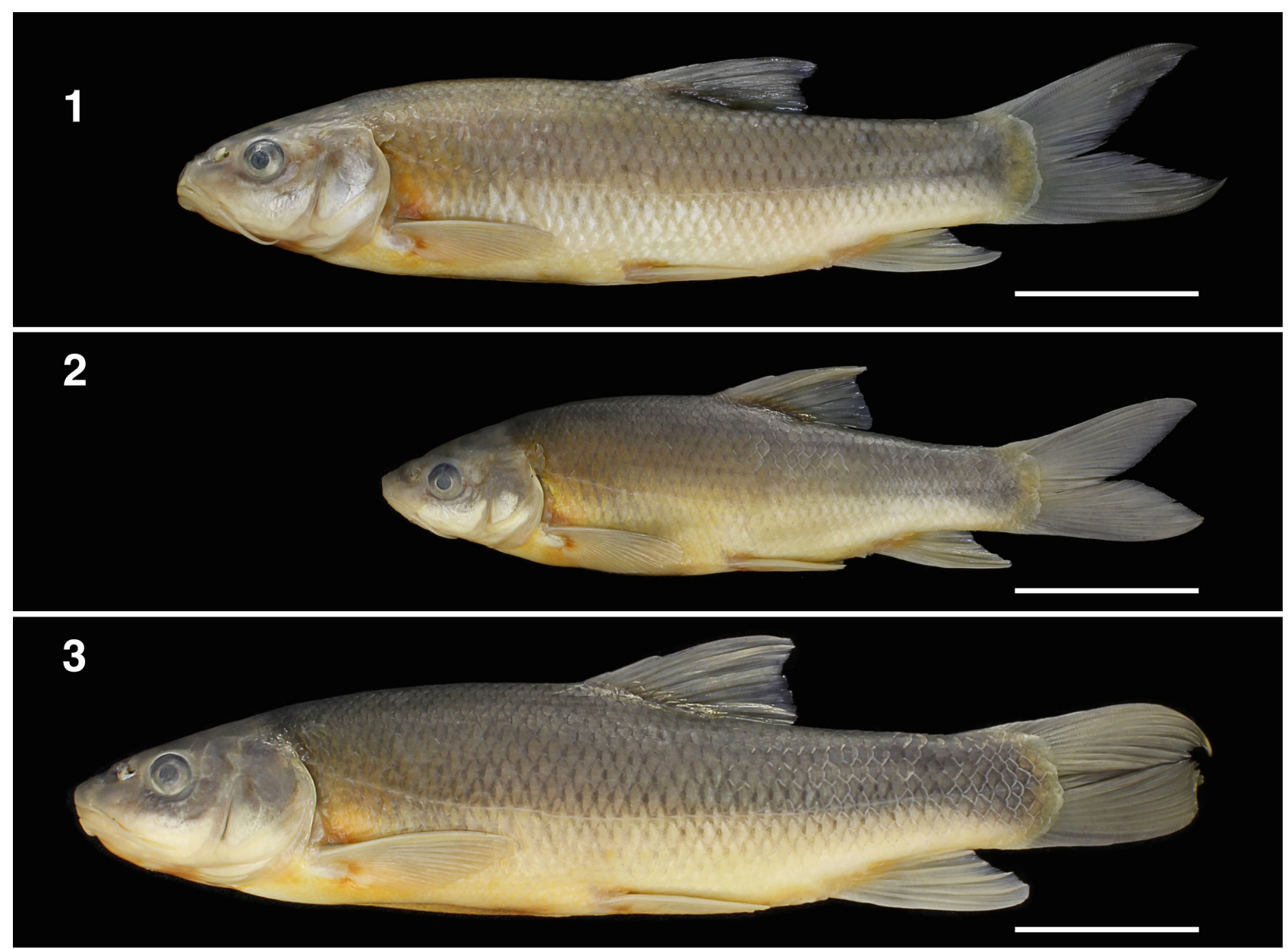

4

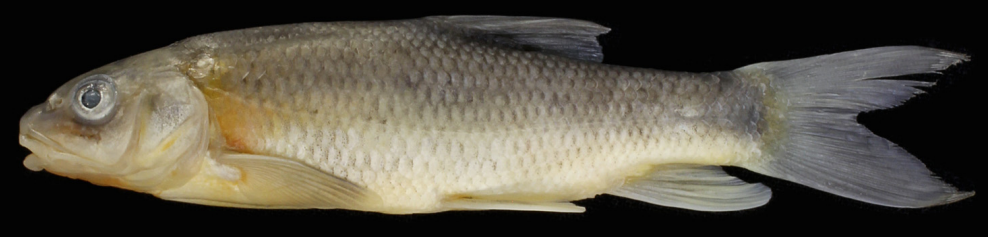

FIGURE 4. Luciobarbus lanigarensis, 1, RMCA 2017-022-P-0024, holotype, 134 mm SL; 2, RMCA 2017-022-P-0020, paratype, $102 \mathrm{~mm}$ SL; 3, RMCA 2017-022-P-0021, paratype, $150 \mathrm{~mm}$ SL; 4, RMCA 2017-022-P-0032, paratype, $93 \mathrm{~mm}$ SL; Morocco: Oued Isly. Scale bars $=30 \mathrm{~mm}$. 
The new species is distinguished from L. callensis, L. chelifensis and L. rifensis by having the last unbranched dorsal-fin ray serrated along $2 / 3$ of its length (vs. last unbranched dorsal-fin ray serrated along almost its entire length) and a longer anal-fin (19-23\% SL vs. 17-19 in L. callensis and L. chelifensis, 16-19 in L. rifensis). The new species is distinguished from L. leptopogon and L. setivimensis by having a greater pre-dorsal distance (53$59 \%$ SL vs. 49-52 in L. leptopogon, 47-52 in L. setivimensis).
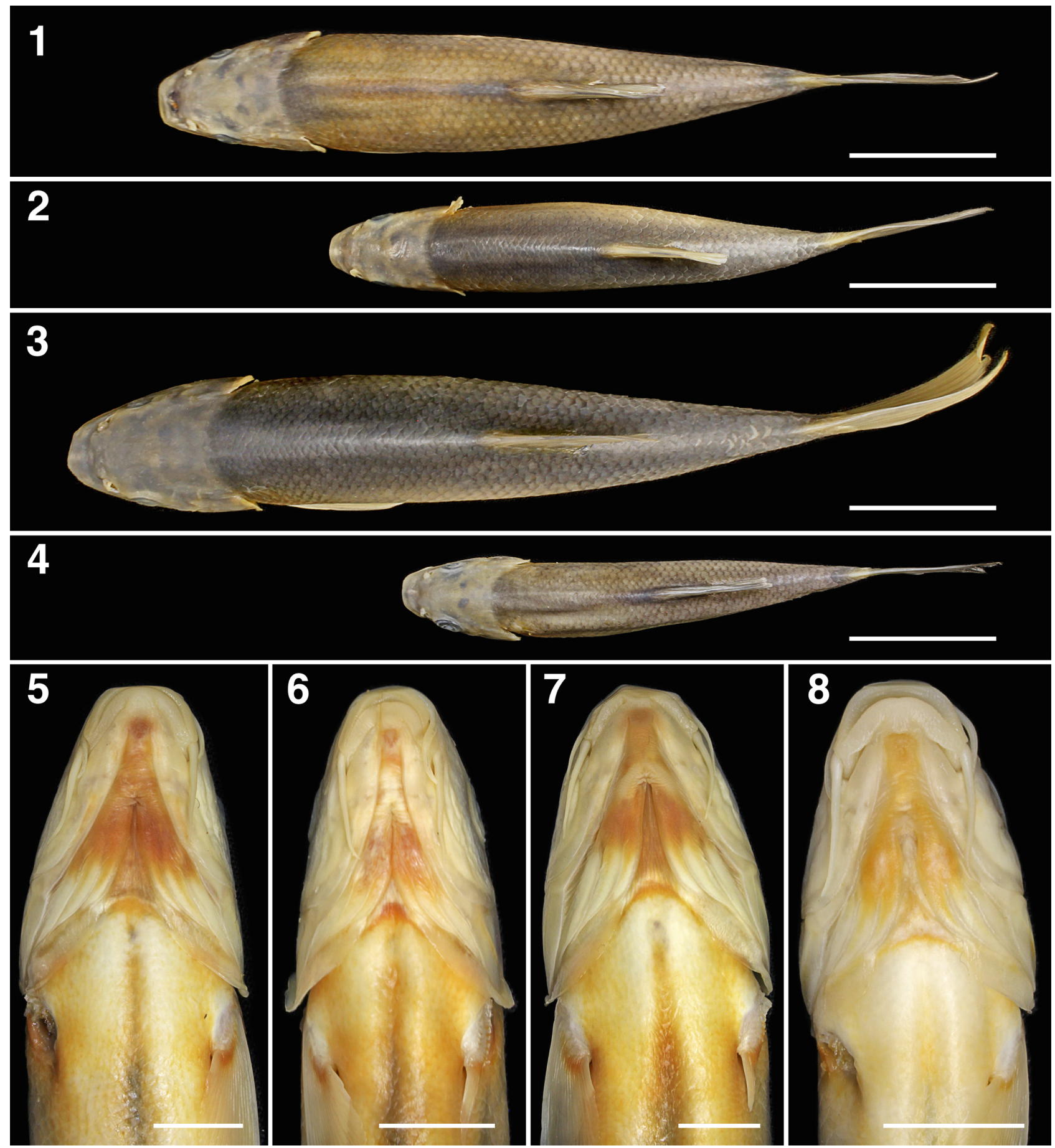

FIGURE 5. Luciobarbus lanigarensis, 1+5, RMCA 2017-022-P-0024, holotype, 134 mm SL; 2+6, RMCA 2017-022-P-0020, paratype, $102 \mathrm{~mm} \mathrm{SL}$; 3+7, RMCA 2017-022-P-0021, paratype, $150 \mathrm{~mm} \mathrm{SL}$; 4+8, RMCA 2018-022-P-0032, paratype, $93 \mathrm{~mm}$ SL; Morocco: Oued Isly. Scale bars: $1-4=30 \mathrm{~mm} ; 5-8=10 \mathrm{~mm}$.

Description. See Figures 3-5 for general appearance. Morphometric data are given in Table 2 and meristic data in Tables 7 and 8. Middle sized and stout species, with a moderately long head. Body deepest at dorsal-fin origin. Depth decreasing continuously towards caudal-fin base. Greatest body width between pectoral and dorsal- 
fin origins. Caudal peduncle compressed, 1.3-1.5 times longer than deep. Section of head roundish, flattened on ventral surface. Snout rounded. Mouth inferior. Dorsal-fin origin situated above pelvic-fin origin. Anal-fin origin at vertical of $50-60 \%$ of distance between dorsal and caudal-fin origins. Anal fin reaching to caudal-fin base. Pectoral fin reaching $70-80 \%$ of distance between pectoral-fin and pelvic-fin origins. Pelvic fin not reaching vertical of tip of last dorsal-fin ray when folded down. Pelvic fin reaching to about $70-90 \%$ of distance between pelvic and analfin origins. Posterior dorsal-fin margin slightly concave. Posterior pectoral- and anal-fin margins convex. Caudal fin forked with rounded lobes of equal length. Largest known specimen $150 \mathrm{~mm} \mathrm{SL}$, but expected to grow larger.

Dorsal fin with 4 unbranched and $81 / 2$ branched rays, last unbranched ray ossified and serrated at $2 / 3$ of its length. Anal fin with 3 unbranched and 51/2 branched rays. Pectoral-fin with 14-17 (mode 16) and pelvic fin with 8 rays. Lateral line with 43-45 scales on flank and 1-3 scales on caudal-fin base. Between dorsal-fin origin and lateral line $8 \frac{1}{2}-91 / 2$ (mode $81 / 2$ ) scale rows, and $5 \frac{1}{2}-6 \frac{1}{2}$ (mode $5 \frac{1}{2}$ ) scale rows between pelvic-fin origin and lateral line. Pharyngeal teeth in three rows: $4+3+2$. On first gill arch, 3-4 gill rakers on the on the upper and 8 on lower limb.

TABLE 3. Morphometric data of Luciobarbus numidiensis (holotype RMCA 2017-022-P-0004; paratypes RMCA 2017022-P-0001-0018, n=13; ZFMK ICH-105604-105605, n=2; non-preserved individuals, $\mathrm{n}=15$ ). The holotype is included in the calculation of ranges, means and SD.

\begin{tabular}{lllll}
\hline & holotype & holotype \& paratypes & & mean \\
\cline { 3 - 5 } & & range & $75-430$ & \\
\hline Standard length (mm) & 140 & & & \\
In percent of standard length & & & & \\
Body depth at dorsal-fin origin & 25.5 & $21.6-28.3$ & 25.1 & 1.7 \\
Head length & 26.1 & $23.1-27.2$ & 5.5 & 0.9 \\
Pre-dorsal length & 52.1 & $48.8-55.2$ & 52.2 & 1.7 \\
Pre-pelvic length & 51.4 & $49.7-55.4$ & 52.8 & 1.7 \\
Pre-anal length & 77.1 & $69.7-80.0$ & 77.6 & 2.3 \\
Dorsal fin base length & 14.5 & $12.7-16.0$ & 14.3 & 0.9 \\
Anal fin base length & 7 & $6.5-10.0$ & 7.9 & 0.7 \\
Anal fin length & 21.6 & $19.1-21.9$ & 20.0 & 0.9 \\
Pelvic fin length & 18.2 & $14.9-20.1$ & 17.1 & 1.7 \\
Pectoral fin length & 23 & $18.5-23.3$ & 20.8 & 1.4 \\
Caudal peduncle length & 18.8 & $16.3-18.8$ & 17.7 & 0.5 \\
Caudal peduncle depth & 13.2 & $12.1-14.0$ & 12.9 & 0.4 \\
Distance between dorsal and anal-fin origins & 33.8 & $30.1-36.0$ & 33.6 & 1.2 \\
Distance between pectoral and pelvic-fin origins & 29.4 & $27.2-30.6$ & 29.2 & 0.6 \\
Distance between pelvic and anal-fin origins & 25.8 & $22.5-26.2$ & 25.3 & 1,1 \\
In percent of head length & & & & 34.5 \\
Snout length & 34 & $29-38$ & 16.1 & 3.4 \\
Eye diameter & 17 & $11-22$ & 49.4 & 1.6 \\
Post-orbital length & 48 & $46-52$ & 39.4 & 1.5 \\
Interorbital distance & 40 & $37-43$ & 81.7 & 6.1 \\
Pectoral-fin length & 88 & $74-94$ & 50.7 & 1.9 \\
Caudal peduncle depth & 50 & $46-54$ & & \\
\hline
\end{tabular}

Coloration. Brown yellowish-golden in life and preserved individuals without colour pattern. Head golden, cheeks and ventral side of head and body whitish. In life, fins orange.

Etymology. Luciobarbus lanigarensis is named for Lanigar, the old name of Ouajda province, given by Claudius Ptolemaeus (100-170). An adjective. 
Distribution. Luciobarbus lanigarensis was found in the Isly River in northestern Morocco, which is a headwater stream of the Tafna River. The Tafna River drainage is situated in the border area between Algeria and Morocco, having its estuary in Algeria close to the city of Tlemcen. Therefore, we expect L. lanigarensis to be found in Algeria also. See Figure 2 (L. lanigarensis are Nr. 28-29) for the distribution of Luciobarbus species from the African Mediterranean Sea basin.

TABLE 4. Morphometric data of L. biscarensis (FSJF 3286, $\mathrm{n}=31$; FSJF 3279, $\mathrm{n}=9$; non-preserved individuals, $\mathrm{n}=24$ ); L. callensis (FSJF 3014, $\mathrm{n}=6$; FSJF 3011, $\mathrm{n}=4$; FSJF 3017, $\mathrm{n}=20$; FSJF 3008, $\mathrm{n}=9$; non-preserved individuals, $\mathrm{n}=21$ ); $L$. leptopogon (FSJF 3284, $\mathrm{n}=9$; RMCA-2016-024-P-0001-0009: $\mathrm{n}=9$; non-preserved individuals, $\mathrm{n}=21$ ).

\begin{tabular}{|c|c|c|c|c|c|c|c|c|c|}
\hline & \multicolumn{3}{|c|}{ L. biscarensis } & \multicolumn{3}{|l|}{ L. callensis } & \multicolumn{3}{|c|}{ L. leptopogon } \\
\hline & range & mean & SD & range & mean & SD & range & mean & SD \\
\hline $\begin{array}{l}\text { Standard length }(\mathrm{mm}) \\
\text {. }\end{array}$ & $50-305$ & & & $44-334$ & & & $76-175$ & & \\
\hline \multicolumn{10}{|l|}{ In percent of standard length } \\
\hline Body depth at dorsal-fin origin & $21.1-28.8$ & 25.3 & 2.0 & $22.0-30.9$ & 26.5 & 2.3 & $20.2-27.0$ & 24.4 & 2.0 \\
\hline Head length & $25.5-28.8$ & 26.8 & 0.7 & $24.3-29.8$ & 26.4 & 1.2 & $23.9-28.3$ & 25.9 & 0.7 \\
\hline Pre-dorsal length & $51.9-57.4$ & 54.4 & 1.2 & $49.4-55.2$ & 52.0 & 1.3 & $48.8-52.6$ & 51.1 & 0.9 \\
\hline Pre-pelvic length & $50.0-56.5$ & 54.3 & 1.4 & $50.6-56.9$ & 53.0 & 1.3 & $51.1-57.1$ & 54.1 & 1.4 \\
\hline Pre-anal length & $73.0-81.2$ & 77.2 & 1.9 & $73.5-81.4$ & 77.1 & 1.7 & $73.6-81.6$ & 78.1 & 2.2 \\
\hline Dorsal fin base length & $11.3-15.4$ & 13.3 & 1.0 & $12.1-15.8$ & 13.9 & 0.9 & $13.9-15.8$ & 14.6 & 0.6 \\
\hline Anal fin base length & $6.0-8.6$ & 7.5 & 0.5 & $6.5-8.4$ & 7.3 & 0.5 & $6.8-10.2$ & 8.4 & 1.0 \\
\hline Anal fin length & $17.3-20.0$ & 18.7 & 0.6 & $16.9-19.0$ & 17.9 & 0.4 & $19.3-21.9$ & 20.5 & 0.6 \\
\hline Pelvic fin length & $12.3-17.8$ & 15.3 & 1.3 & $13.9-20.5$ & 16.4 & 1.5 & $16.3-20.0$ & 17.8 & 1.1 \\
\hline Pectoral fin length & $16.1-21.2$ & 18.3 & 1.1 & $17.7-23.1$ & 20.4 & 1.2 & $17.9-22.9$ & 20.2 & 1.3 \\
\hline Caudal peduncle length & $16.5-19.3$ & 17.6 & 0.7 & $15.1-20.5$ & 17.3 & 0.9 & $15.0-19.5$ & 17.3 & 1.0 \\
\hline Caudal peduncle depth & $11,0-13.3$ & 11.8 & 0.7 & $11.0-14.1$ & 12.6 & 0.5 & $10.5-12.9$ & 11.8 & 0.5 \\
\hline Distance between dorsal and anal-fin origins & $27.3-36.4$ & 31.3 & 2.0 & $29.7-39.3$ & 34.4 & 1.7 & $30.1-38.2$ & 33.7 & 1.7 \\
\hline Distance between pectoral and pelvic-fin origins & $21.8-30.2$ & 27.4 & 1.6 & $22.5-29.3$ & 26.6 & 1.4 & $25.6-31.2$ & 28.2 & 1.6 \\
\hline Distance between pelvic and anal-fin origins & $19.0-27.1$ & 23.0 & 1.7 & $20.4-27.7$ & 24.1 & 1.7 & $20.6-26.9$ & 24.0 & 1.6 \\
\hline \multicolumn{10}{|l|}{ In percent of head length } \\
\hline Snout length & $30-39$ & 34.5 & 2.2 & $24-41$ & 33.8 & 4.8 & $29-34$ & 32.1 & 1.2 \\
\hline Eye diameter & $9-21$ & 15.6 & 4.0 & $11-28$ & 16.6 & 5.0 & $17-24$ & 20.6 & 1.5 \\
\hline Post-orbital length & $44-53$ & 49.9 & 2.7 & $44-50$ & 47.6 & 1.0 & $45-50$ & 47.4 & 0.9 \\
\hline Interorbital distance & $31-39$ & 35.5 & 1.9 & $32-42$ & 36.9 & 1.9 & $36-39$ & 38.0 & 0.9 \\
\hline Pectoral-fin length & $61-78$ & 68.2 & 4.1 & $69-84$ & 77.2 & 3.3 & $63-90$ & 78.0 & 5.7 \\
\hline Caudal peduncle depth & $41-47$ & 43.8 & 1.7 & $40-53$ & 47.8 & 2.8 & $41-59$ & 45.7 & 2.1 \\
\hline
\end{tabular}

\section{Luciobarbus numidiensis, new species}

(Figs. 6-8)

Holotype. RMCA 2017-022-P-0004, 140 mm SL; Algeria: Mila prov.: Oued El-Kébir at Hammam Beni Haroun, $36.6053^{\circ} \mathrm{N}, 6.2783^{\circ} \mathrm{E}$.

Paratypes. RMCA 2017-022-P-0001-0007, 6, 99-162 mm SL; same data as holotype--RMCA 2017-022-P0008-0011, 4, 45-78 mm SL; Algeria: Jijel prov.: Oued Saleh at Borj Bou Akkaz, 36.4915 ${ }^{\circ}$, 5.8894 ${ }^{\circ}$ E.-RMCA 2017-022-P-0012-0018, 5, 73-150 mm SL; ZFMK ICH-105604-105605, 2, 100-109 mm SL; Algeria: Mila prov.: Oued El-Kébir at Hammam Beni Haroun, $36.6053^{\circ} \mathrm{N}, 6.2783^{\circ} \mathrm{E}$.

Material for molecular analyses. RMCA DNA-2017-022-P-NH1-NH6, same data as holotype (GenBank accession numbers: Cyt b: MH187177, MH187179, MH187182, MH187183, MH187187; D-loop: MH187200, 
MH187203, MH187205, MH187206, MH187210).-RMCA DNA-2017-022-P-NH16-NH27, Algeria: Mila prov.: Beni-Haroun reservoir at Oued El-Kébir, 36.3319, 6.1611 (GenBank accession numbers: Cyt b: MH187175, MH187176, MH187178, MH187180, MH187181, MH187184, MH187185, MH187186, MH187188; D-loop: MH187198, MH187199, MH187201, MH187202, MH187204, MH187207, MH187208, MH187209, MH187211).

Diagnosis. Luciobarbus numidiensis is distinguished from other Luciobarbus species from the African Mediterranean Sea basin, by a combination of characters, none of them unique. Luciobarbus numidiensis is distributed adjacent to $L$. callensis in the east and L. setivimensis in the west.

It is distinguished from $L$. callensis by having a longer anal-fin (19-23\% SL vs. 16-19\%), a wider anal-fin base (6.5-10\% SL vs. $6.5-8)$ and a longer distance between the pectoral and pelvic-fin origins (27-30\% SL vs. $22-$ 29). The new species is distinguished from $L$. setivimensis by the having a longer pectoral-fin (74-94\% HL vs. 69 84), a longer pre-dorsal length (49-55\% SL vs. 46-52), a wider caudal peduncle depth (12-14\% SL vs. 11-13) and a smaller eye diameter (11-22\% HL vs. 11-28\%).

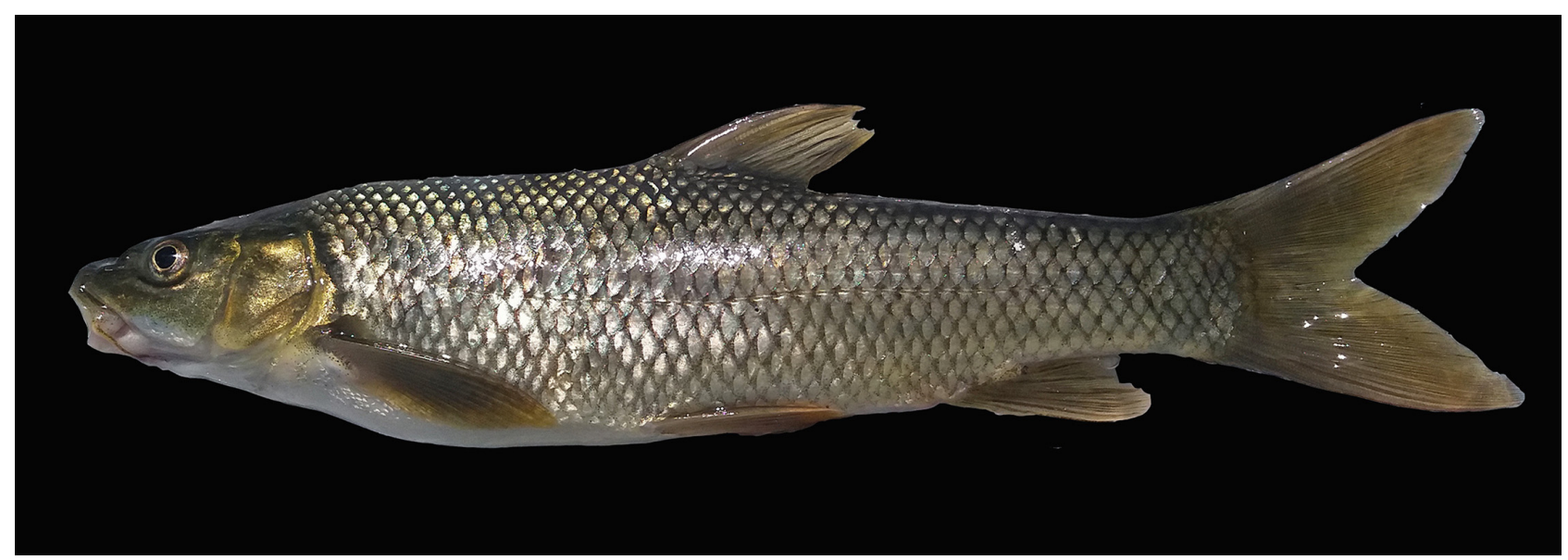

FIGURE 6. Luciobarbus numidiensis, RMCA 2017-022-P-0004, holotype, 140 mm SL; Algeria: Oued El-Kébir.

The new species is distinguished from L. guercifensis by having thin barbels (vs. thick), the rostral-barbel origin placed clearly behind the tip of the snout (vs. rostral-barbel origin at the extreme anterior of the snout). It is distinguished from L. chelifensis, L. mascarensis and L. leptopogon by having 43-47+1-2 lateral line scales (vs. 41-43+1-2 in L. chelifensis and L. leptopogon, usually 41+1-2 in L. mascarensis) (Table 8).

Luciobarbus numidiesis is further distinguished from L. chelifensis and L. rifensis hy having a longer anal fin (19-22\% SL vs. 17-19 in L. chelifensis, 16-19 in L. rifensis). The new species is distinguished from L. leptopogon by having a greater caudal peduncle depth $(12-14 \%$ SL vs. $10-13)$ and from L. yahyaouii by having a longer distance between the pelvic and anal-fin origins (23-26\% SL vs. 20-24).

It is also distinguished from L. mascarensis, L. lanigarensis and L. yahyaouii by having a shorter pre-dorsal length (48-55\% SL vs. 53-58 in L. mascarensis, 54-59 in L. lanigarensis, 53-57 in L. yahyaouii). The new species is also distinguished from $L$. lanigarensis by having a smaller pre-pelvic length (49-56\% SL vs. 55-60\%), a greater post-orbital length (46-52\% HL vs. $42-48$ ) and the last unbranched dorsal-fin ray ossified and serrated at $2 / 3$ of its length (vs. last unbranched dorsal-fin ray serrated along almost its entire length).

Description. See Figures 6-8 for general appearance. Morphometric data are given in Table 3 and meristic data in Table 7 and 8. A large-sized species with a moderately long head. Body deepest at dorsal-fin origin or about midline between nape and dorsal-fin origin. Depth decreasing continuously towards caudal-fin base. Greatest body width in front of dorsal-fin origin. Caudal peduncle compressed, 1.2-1.5 times longer than deep. Section of head roundish, flattened on ventral surface. Snout rounded. Mouth inferior. Dorsal-fin origin situated above pelvic-fin origin. Anal-fin origin slightly behind vertical of middle between dorsal and caudal-fin origins. Anal-fin origin slightly behind vertical of middle of distance between dorsal and caudal-fin origins. Anal fin reaching to caudal-fin base. Pectoral fin reaching $60-80 \%$ of distance between pectoral- and pelvic-fin origin. Pelvic fin not reaching vertical of tip of last dorsal-fin ray when folded down. Pelvic fin reaching to $60-90 \%$ of distance between pelvic and anal-fin origins. Posterior dorsal-fin margin straight or slightly concave. Posterior pectoral and anal-fin margins convex. Caudal fin forked with rounded lobes of equal length. Largest known specimen $430 \mathrm{~mm}$ SL. 

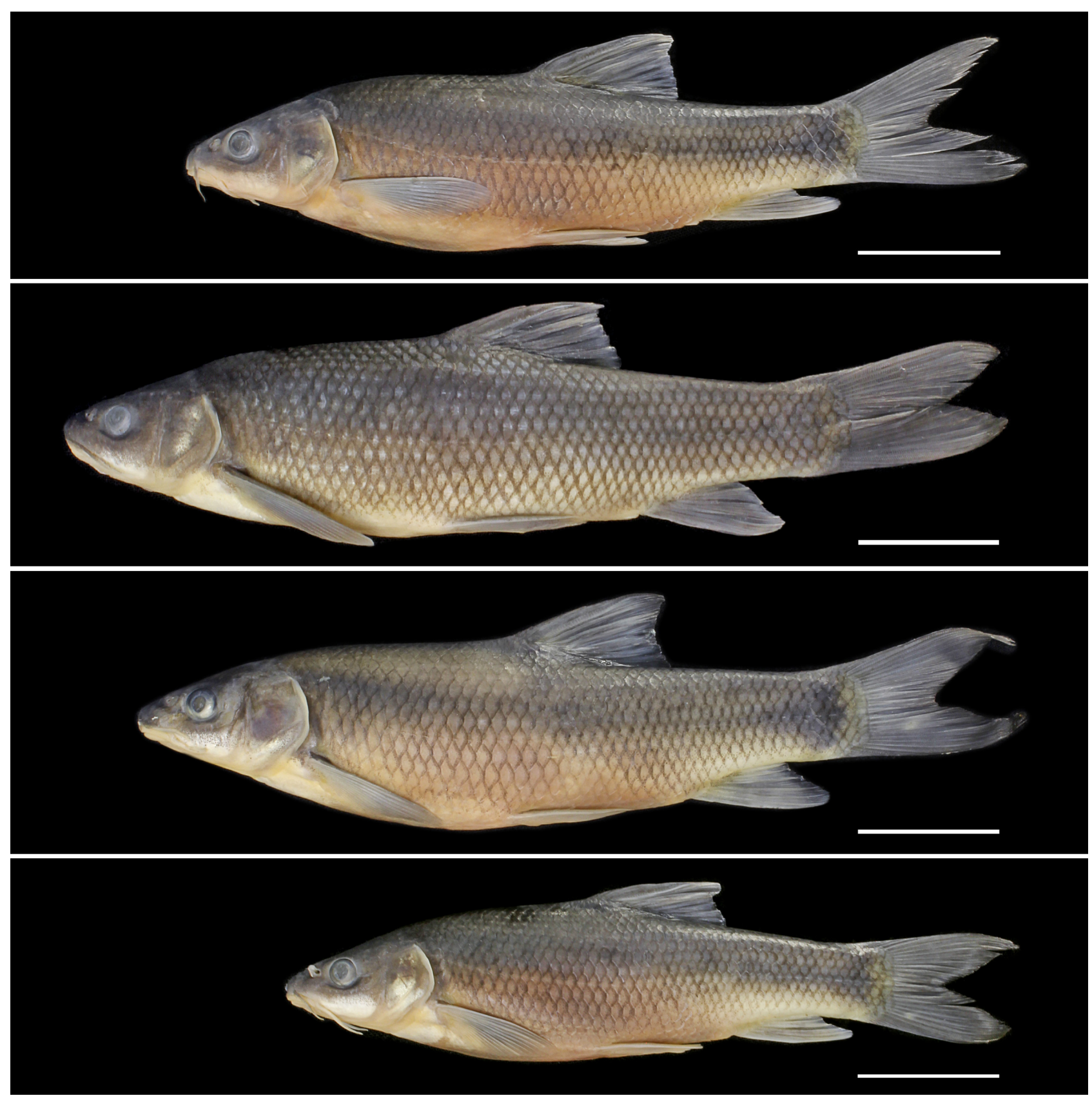

FIGURE 7. Luciobarbus numidiensis, 1, RMCA 2017-022-P-0004, holotype, 140 mm SL; 2, RMCA 2017-022-P-0002, paratype, $162 \mathrm{~mm}$ SL; 3, RMCA 2017-022-P-0006, paratype, $148 \mathrm{~mm} \mathrm{SL;} \mathrm{4,} \mathrm{RMCA} \mathrm{2017-022-P-0007,} \mathrm{paratype,} 121 \mathrm{~mm}$ SL; Algeria: Oued El-Kébir. Scale bars $=30 \mathrm{~mm}$.

Dorsal fin with 4 or 5 unbranched and $81 / 2$ branched rays, last unbranched ray serrated along almost its entire length. Anal fin with 3 unbranched and 51/2 branched rays. Pectoral-fin with 13-18 rays (mode 17) and pelvic fin with 8 rays. Lateral line with 43-47 scales on flank and 1-2 scales on caudal-fin base. Between dorsal-fin origin and lateral line $8 \frac{1}{2}-9 \frac{1}{2}$ (mode $9 \frac{1}{2}$ ) scale rows and 51/2-61/2 (mode $5 \frac{1}{2}$ ) scale rows between pelvic-fin origin and lateral line. Pharyngeal teeth in three rows: $4+3+2$. On first gill arch, 3-4 gill rakers on upperand 8-10 on lower limb.

Coloration. In life, whitish-golden on belly, silvery-grey on flank and dark-grey on back. Head golden-grey and cheeks greenish-golden. All fins grey. Pectoral fin with a golden distal edge.

Etymology. Luciobarbus numidiensis is named for Numidia, an ancient Berber kingdom, located in Algeria. The capital of Numidia was Cirta, the present city of Constantine. The El-Kebir River, the habitat of $L$. numidiensis, flows through Constantine. An adjective. 

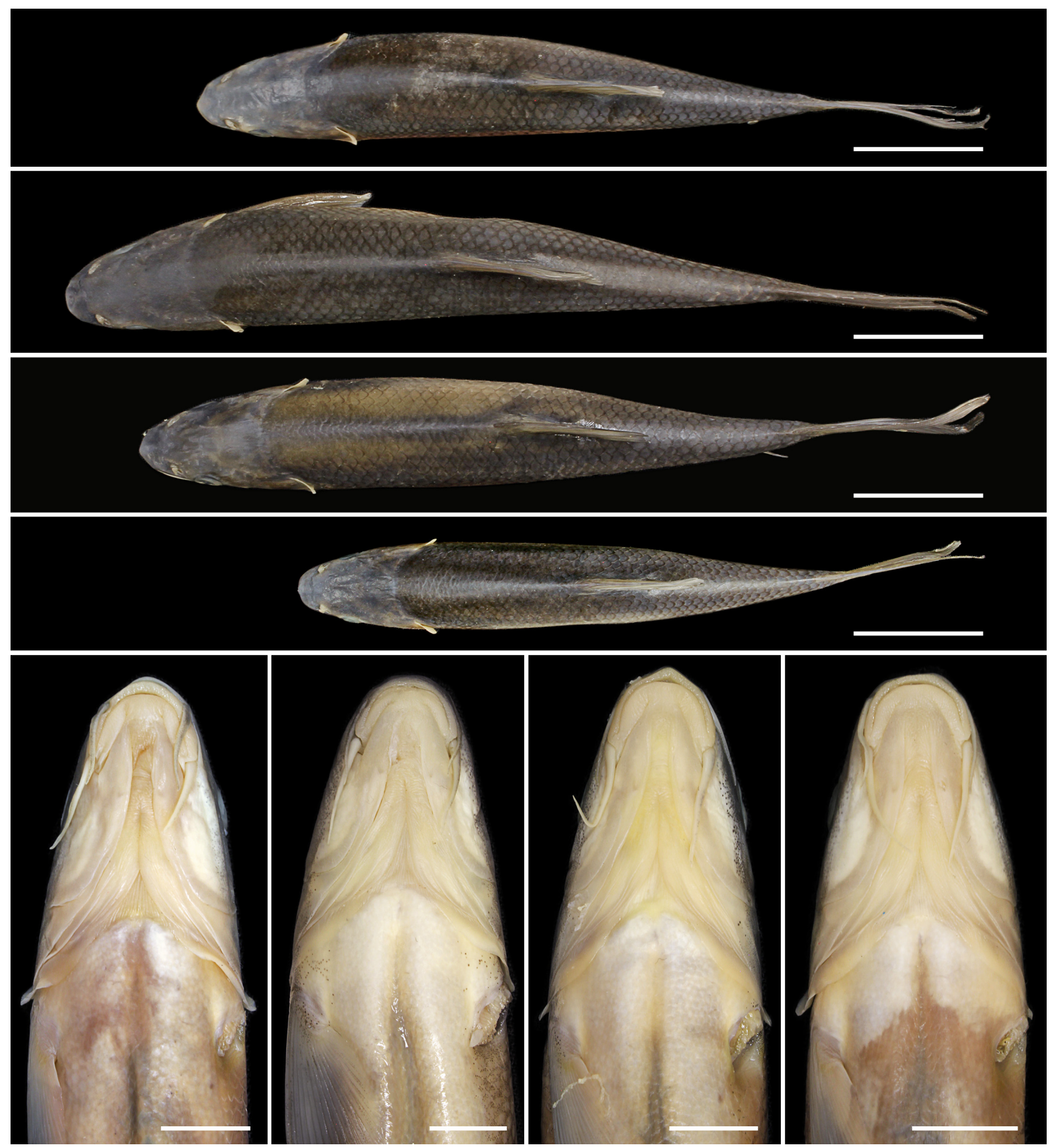

FIGURE 8. Luciobarbus numidiensis, 1+5, RMCA 2017-022-P-0004, holotype, 140 mm SL; 2+6, RMCA 2017-022-P-0002, paratype, $162 \mathrm{~mm} \mathrm{SL;} \mathrm{3+7,} \mathrm{RMCA} \mathrm{2017-022-P-0006,} \mathrm{paratype,} 148 \mathrm{~mm}$ SL; 4+8, RMCA 2017-022-P-0007, paratype, 121 mm SL; Algeria: Oued El-Kébir. Scale bars: $1-4=30 \mathrm{~mm} ; 5-8=10 \mathrm{~mm}$.

Distribution. Luciobarbus numidiensis was found in the El-Kébir River and in the Beni Haroun reservoir, both belonging to the El-Kébir River drainage in northestern Algeria. See Figure 2 (L. numidiensis are Nr. 10-12) for the distribution of Luciobarbus species in the African Mediterranean Sea basin.

Remarks. Luciobarbus numidiensis occurs north of the range of L. biscarensis, which is found in the rivers of the Algerian Sahara. It is distinguished from this species by having 43-47+1-2 lateral line scales (vs. 49-51+1-2), $5 \frac{1}{2}-6^{1 / 2}$ scale rows between the lateral line and the pelvic-fin origin (vs. $7 \frac{1}{2}-8^{1} \frac{1}{2}$ ), 4 at 5 unbranched dorsal-fin rays (vs. 5), the dorsal-fin origin situated above the pelvic-fin origin (vs. behind), a longer anal fin (19-22\% SL vs. 1719) and a more wider interorbital distance (37-43\% HL vs. 31-39). 
TABLE 5. Morphometric data of L. rifensis (FSJF 3335, $\mathrm{n}=19$ ); L. setivimensis (FSJF 3289, $\mathrm{n}=15$; FSJF 3297, $\mathrm{n}=13$; FSJF 3292, n=19; non-preserved individuals, $\mathrm{n}=10$ ); L. yahyaouii (FSJF 3331, n=10; FSJF 3313, n=19).

\begin{tabular}{|c|c|c|c|c|c|c|c|c|c|}
\hline & \multicolumn{3}{|l|}{ L. rifensis } & \multicolumn{3}{|c|}{ L. setivimensis } & \multicolumn{3}{|c|}{ L. yahyaouii } \\
\hline & range & mean & SD & range & mean & SD & range & mean & SD \\
\hline Standard length (mm) & $80-208$ & & & $61-363$ & & & $67-181$ & & \\
\hline \multicolumn{10}{|l|}{ In percent of standard length } \\
\hline Body depth at dorsal-fin origin & $25.5-32.6$ & 29.3 & 1.8 & $21.0-31.5$ & 26.6 & 2.5 & $24.5-32.1$ & 28.3 & 1.9 \\
\hline Head length & $23.7-27.8$ & 25.6 & 0.9 & $22.4-28.4$ & 25.0 & 1.7 & $24.6-30.7$ & 27.0 & 1.5 \\
\hline Pre-dorsal length & $50.5-54.5$ & 52.3 & 1.2 & $46.7-52.2$ & 50.3 & 1.3 & $52.7-56.9$ & 54.0 & 1.1 \\
\hline Pre-pelvic length & $50.5-56.4$ & 53.1 & 1.6 & $48.4-54.8$ & 51.7 & 1.4 & $52.7-57.0$ & 54.5 & 1.2 \\
\hline Pre-anal length & $74.6-81.8$ & 76.9 & 1.6 & $73.3-79.5$ & 76.1 & 1.6 & $75.4-80.6$ & 77.2 & 1.3 \\
\hline Dorsal fin base length & $12.1-14.9$ & 13.4 & 0.9 & $11.5-16.3$ & 14.1 & 1.1 & $12.9-15.2$ & 13.9 & 0.6 \\
\hline Anal fin base length & $6.7-8.2$ & 7.3 & 0.5 & $6.4-9.4$ & 8.3 & 0.7 & $7.8-9.0$ & 8.5 & 0.3 \\
\hline Anal fin length & $15.9-18.9$ & 17.7 & 0.8 & $19.0-21.6$ & 19.8 & 0.4 & $19.1-21.3$ & 20.1 & 0.7 \\
\hline Pelvic fin length & $11.7-17.7$ & 16.1 & 1.4 & $13.5-19.2$ & 16.8 & 1.5 & $15.9-18.6$ & 17.3 & 0.7 \\
\hline Pectoral fin length & $17.2-20.6$ & 19.4 & 0.9 & $16.8-22.3$ & 19.7 & 1.2 & $18.4-21.3$ & 19.9 & 0.7 \\
\hline Caudal peduncle length & $16.1-19.6$ & 17.8 & 1.2 & $14.4-18.4$ & 17.1 & 0.8 & $16.1-19.4$ & 17.5 & 0.8 \\
\hline Caudal peduncle depth & $11.6-13.4$ & 12.2 & 0.4 & $11.1-13.5$ & 12.3 & 0.7 & $11.0-12.8$ & 12.2 & 0.5 \\
\hline Distance between dorsal and anal-fin origins & $30.5-39.5$ & 35.3 & 2.1 & $32.2-39.0$ & 35.4 & 1.6 & $31.3-38.3$ & 35.1 & 1.8 \\
\hline $\begin{array}{l}\text { Distance between pectoral and pelvic-fin } \\
\text { origins }\end{array}$ & $25.1-32.4$ & 27.5 & 1.8 & $22.1-30.4$ & 26.7 & 1.8 & $24.0-30.8$ & 27.6 & 1.5 \\
\hline Distance between pelvic and anal-fin origins & $20.7-27$ & 23.8 & 1.5 & $19.2-28.9$ & 24.4 & 1.9 & $20.8-24.0$ & 22.7 & 1.0 \\
\hline \multicolumn{10}{|l|}{ In percent of head length } \\
\hline Snout length & $26-40$ & 32.5 & 4.1 & $27-38$ & 32.9 & 2.6 & $28-37$ & 32.0 & 2.1 \\
\hline Eye diameter & $14-24$ & 20.6 & 2.6 & $11-28$ & 16.6 & 5.0 & $15-26$ & 20.9 & 2.8 \\
\hline Post-orbital length & $42-51$ & 47.0 & 2.4 & $45-50$ & 47.6 & 1.0 & $45-50$ & 47.1 & 1.5 \\
\hline Interorbital distance & $34-41$ & 37.5 & 1.8 & $40-44$ & 41.5 & 1.9 & $33-40$ & 38.0 & 1.8 \\
\hline Pectoral-fin length & $66-84$ & 75.9 & 4.1 & $69-84$ & 77.2 & 3.3 & $65-79$ & 74.0 & 3.6 \\
\hline Caudal peduncle depth & $45-52$ & 47.8 & 2.2 & $40-53$ & 47.8 & 2.8 & $40-52$ & 45.3 & 3.1 \\
\hline
\end{tabular}

Luciobarbus numidiensis is quite variable in the serration of the last unbranched dorsal-fin ray. Specimens collected from the Beni-Haroun reservoir have the last unbranched dorsal-fin ray serrated along $2 / 3$ of its length with sparsely set denticulations while fish collected from the El-Kébir River have the last unbranched dorsal-fin ray serrated along almost its entire length with densely set denticulations.

\section{Discussion}

This study follows Casal-Lopez et al. (2015), Doadrio et al. (2016a, 2016b) and Brahimi et al. (2017) in describing new species of African Luciobarbus based largely on molecular distances. We further made considerable efforts to detect external morphological characters usable for an univocal identification of the different Luciobarbus species from the African Mediterranean Sea basin. However, this exercise was found to be frustrating. Most species are very similar in their morphometric and meristic characters and almost all morphometric and meristic ranges overlap; larger overlaps are expected if larger series of specimens are examined. This is especially the case for $L$. callensis, L. numidiensis and L. setivimensis. However, all these allopatric species are well differentiated genetically and show sibstances molecular distances $(L$. callensis / L. numidiensis $=4.3 \%$; L. setivimensis $/ L$. numidiensis $=8.8 \%$ ). 
TABLE 6. Morphometric data of $L$. chelifensis (RMCA 2016-024-P-0010-0016, $\mathrm{n}=7$; non-preserved individuals, $\mathrm{n}=19$ ); L. mascarensis (RMCA 2016-024-P-0017-0026, $\mathrm{n}=10$; non-preserved individuals, $\mathrm{n}=15$ ).

\begin{tabular}{|c|c|c|c|c|c|c|}
\hline & \multicolumn{3}{|c|}{ L. chelifensis } & \multicolumn{3}{|c|}{ L. mascarensis } \\
\hline & range & mean & SD & range & mean & SD \\
\hline Standard length (mm) & $102-296$ & & & $63.5-185$ & & \\
\hline \multicolumn{7}{|l|}{ In percent of standard length } \\
\hline Body depth at dorsal-fin origin & $24.8-31.3$ & 27.6 & 1.3 & $26.2-30.6$ & 28.6 & 1.1 \\
\hline Head length & $22.4-26.4$ & 24.2 & 1.2 & $24.4-28.0$ & 26.1 & 0.8 \\
\hline Pre-dorsal length & $49-54.2$ & 51.6 & 1.1 & $52.5-58.3$ & 54.6 & 1.4 \\
\hline Pre-pelvic length & $50.3-56$ & 53.4 & 1.6 & $50.0-58.3$ & 54.4 & 1.7 \\
\hline Pre-anal length & $73.8-79.3$ & 77.3 & 1.6 & $73.3-85.1$ & 79.9 & 1.9 \\
\hline Dorsal fin base length & $12.8-15.2$ & 13.6 & 0.6 & $12.1-15.3$ & 13.8 & 0.8 \\
\hline Anal fin base length & $8.5-9.9$ & 9.0 & 0.4 & $6.6-9.6$ & 7.9 & 0.6 \\
\hline Anal fin length & $17.6-18.5$ & 18.1 & 0.3 & $19.1-21.7$ & 20.1 & 0.7 \\
\hline Pelvic fin length & $14.1-16.2$ & 15.2 & 0.6 & $14.3-19.4$ & 15.8 & 1.2 \\
\hline Pectoral fin length & $17.4-20.7$ & 19.0 & 0.9 & $16.4-21.3$ & 18.5 & 1.3 \\
\hline Caudal peduncle length & $14.0-18.3$ & 15.7 & 1.3 & $15.2-17.1$ & 16.3 & 0.5 \\
\hline Caudal peduncle depth & $11.2-12.7$ & 11.9 & 0.5 & $11.8-13.3$ & 12.6 & 0.4 \\
\hline Distance between dorsal and anal-fin origins & $32.9-38.3$ & 35.6 & 1.3 & $32.8-38.1$ & 34.9 & 1.3 \\
\hline Distance between pectoral and pelvic-fin origins & $25.5-31.3$ & 29.2 & 1.5 & $25.8-31.4$ & 28.3 & 1.4 \\
\hline Distance between pelvic and anal-fin origins & $20.6-27.6$ & 23.9 & 1.2 & $24.1-28.2$ & 25.6 & 1.2 \\
\hline \multicolumn{7}{|l|}{ In percent of head length } \\
\hline Snout length & $27-37$ & 32.2 & 2.9 & $26-38$ & 32.3 & 2.8 \\
\hline Eye diameter & $14-18$ & 16.3 & 1.0 & $15-28$ & 21.8 & 2.7 \\
\hline Post-orbital length & $47-55$ & 51.5 & 2.6 & $44-48$ & 45.9 & 0.7 \\
\hline Interorbital distance & $36-40$ & 37.9 & 0.8 & $36-40$ & 38.8 & 0.8 \\
\hline Pectoral-fin length & $70-85$ & 78.7 & 4.2 & $61-80$ & 70.8 & 5.2 \\
\hline Caudal peduncle depth & $46-52$ & 49.2 & 1.2 & $46-53$ & 48.5 & 1.2 \\
\hline
\end{tabular}

TABLE 7. Frequencies of meristic characters: unbranched dorsal-fin rays and branched fin rays of Luciobarbus species examined for this study.

\begin{tabular}{|c|c|c|c|c|c|c|c|c|c|c|}
\hline \multirow[t]{2}{*}{ Species } & \multirow[t]{2}{*}{$\mathrm{N}$} & \multicolumn{3}{|c|}{ unbranched dorsal-fin rays } & \multirow[t]{2}{*}{$\mathrm{N}$} & \multicolumn{3}{|c|}{ branched dorsal-fin rays } & \multicolumn{2}{|c|}{ branched pelvic-fin rays } \\
\hline & & 3 & 4 & 5 & & $71 / 2$ & $81 / 2$ & $91 / 2$ & 7 & 8 \\
\hline L. biscarensis & 26 & & & 26 & 64 & 5 & 59 & & 22 & 42 \\
\hline L. callensis & 23 & & 19 & 4 & 60 & & 60 & & & 60 \\
\hline L. chelifensis & 15 & & 15 & & 26 & & 26 & & 2 & 24 \\
\hline L. leptopogon & 18 & & 18 & & 39 & 4 & 35 & & 1 & 38 \\
\hline L. mascarensis & 13 & & 13 & & 29 & & 29 & & 5 & 24 \\
\hline L. lanigarensis & 10 & & 10 & & 23 & & 23 & & & 23 \\
\hline L. numidiensis & 11 & & 6 & 5 & 15 & & 15 & & & 15 \\
\hline L. rifensis & 19 & & 13 & 6 & 19 & & 19 & & & 19 \\
\hline L. setivimensis & 30 & 8 & 22 & & 57 & & 57 & & 4 & 53 \\
\hline L. yahyaouii & 19 & & 1 & 18 & 29 & & 27 & 2 & 4 & 25 \\
\hline
\end{tabular}


TABLE 8. Frequencies of lateral-line scales on flank in Luciobarbus species examined for this study.

\begin{tabular}{|c|c|c|c|c|c|c|c|c|c|c|c|c|}
\hline \multirow[t]{2}{*}{ Species } & \multirow[t]{2}{*}{$\mathrm{N}$} & \multicolumn{11}{|c|}{ Scales along the lateral line } \\
\hline & & 41 & 42 & 43 & 44 & 45 & 46 & 47 & 48 & 49 & 50 & 51 \\
\hline L. biscarensis & 26 & & & & & & & & & 8 & 2 & 16 \\
\hline L. callensis & 34 & & & 2 & 5 & 16 & 9 & 2 & & & & \\
\hline L. chelifensis & 15 & 4 & 9 & 2 & & & & & & & & \\
\hline L. leptopogon & 18 & 5 & 8 & 5 & & & & & & & & \\
\hline L.mascarensis & 15 & 14 & & 1 & & & & & & & & \\
\hline L. lanigarensis & 18 & & & 13 & 2 & 3 & & & & & & \\
\hline L. numidiensis & 29 & & & 3 & 2 & 6 & 1 & 17 & & & & \\
\hline L. rifensis & 19 & & & 10 & 6 & 3 & & & & & & \\
\hline L. setivimensis & 30 & & & 6 & 9 & 5 & 8 & 2 & & & & \\
\hline L. yahyaouii & 19 & & 6 & 7 & 4 & 2 & & & & & & \\
\hline
\end{tabular}

Recently, Clavero et al. (2017:10) showed stunning examples of how head and body shape might be variable in African Luciobarbus species. They speculate that this substantial morphological variability might correspond to the very high ecological plasticity of these barbels, which indeed inhabit almost all kinds of waterbodies. With regard to the paucity of diagnostic morphological characters, the inclusion of molecular genetic characters into standard taxonomic works in Luciobarbus is of great value but makes it very difficult to identify species in the field.

\section{Comparative material.}

Numbers in brackets correspond to Figure 2.

Luciobarbus biscarensis: FSJF 3286, 31, 69-190 mm SL; Algeria: Biskra prov.: Oued el Abiod above damlake at

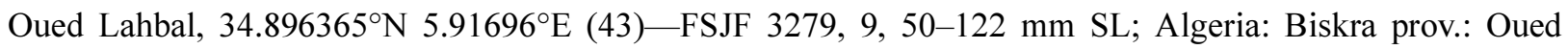
Loutaya at Manbae, $35.094477^{\circ} \mathrm{N} 5.586152^{\circ} \mathrm{E}(45)$.

Luciobarbus callensis. FSJF 3014, 6, 35-97 mm SL; Tunisia: Oued el Abid about $2 \mathrm{~km}$ west of Erritiba, $36.867286^{\circ} \mathrm{N} 10.724574^{\circ} \mathrm{E}(2)$. - FSJF 3011, 4, 36-94 mm SL; Tunisia: Oued Ghezala $1 \mathrm{~km}$ south of Fernana, $36.643868^{\circ} \mathrm{N} 8.699214^{\circ} \mathrm{E}(5) .-\mathrm{FSJF}$ 3017, 20, 60-210 mm SL; Tunisia: Kébir River below Zouitina reservoir, $36.732208^{\circ} \mathrm{N} 8.529498^{\circ} \mathrm{E}$ (6).-FSJF 3008, 9, 71-145 mm SL; Tunisia: Oued Zahzah $2 \mathrm{~km}$ south of Bechechema, $35.821259^{\circ} \mathrm{N} 10.159296^{\circ} \mathrm{E}(3)$.

Luciobarbus chelifensis: RMCA 2016-024-P-0010-0016, 7, 102-152 SL; Algeria: Chelif prov.: Oued Sly west of Ouled Ben Abdelkader village, 36.026609 ${ }^{\circ} \mathrm{N} 1.266014^{\circ} \mathrm{E}$ (22). ZFMK ICH-105597-105601, 5, 82-122 mm SL; Algeria: Ain Defla prov.: Ghrib reservoir at Oued Chorffa, $36.140553^{\circ} \mathrm{N} 2.563226^{\circ} \mathrm{E}(21)$.

Luciobarbus guercifensis: ZFMK ICH-105305,1, 115 mm SL; Morocco: Oued Za near Guefait, Moulouya, $34.226706^{\circ} \mathrm{N} 2.392343^{\circ} \mathrm{W}(30)$.

Luciobarbus leptopogon: FSJF 3284, 9, 97-128 mm SL; Algeria: stream Meliji at Hammam Melouane, 36.4829 $\mathrm{N}, 3.0414^{\circ} \mathrm{E}$ (20).-RMCA-2016-024-P-0001-0009: 9, 76-133 mm SL; Algeria: Blida prov.: Oued Hammam Melouane, $36.4829^{\circ} \mathrm{N}, 3.0414^{\circ} \mathrm{E}(20)$.

Luciobarbus mascarensis: FSJF 3283, 4, 75-121 mm SL; Algeria: Mascara prov.: Oued El Hammam upriver of Hocine, $35.444265^{\circ} \mathrm{N}, 0.035043^{\circ} \mathrm{E}$ (27).-RMCA 2016-024-P-0017-0026, 10, 66-188 mm SL; Algeria: Mascara prov.: Oued Taria north of Meftah Sidi Boubekeur, $35.109848^{\circ} \mathrm{N}, 0.0673^{\circ} \mathrm{E}(26)$.

Luciobarbus rifensis: FSJF 3335, 19, 80-208 mm SL; Morocco: Laou River near Chefchaouene, $35.168483^{\circ} \mathrm{N}$ $5.314508^{\circ} \mathrm{W}(36)$.

Luciobarbus setivimensis: FSJF 3289, 15, 66-156 mm SL; Algeria: Oued Zitouna at Tala Khaled, $36.634327^{\circ} \mathrm{N}$ $5.216879^{\circ} \mathrm{E}(15) .-\mathrm{FSJF} 3297,13,132-225 \mathrm{~mm}$ SL; Algeria: Oued Boughzazene at Boughzazene, $36.614407^{\circ} \mathrm{N} 5.361913^{\circ} \mathrm{E}(14)$. - FSJF 3292, 19, 66-156 mm SL; Algeria: Oued Remila at inflow into Oued Soummam, $36.632246^{\circ} \mathrm{N} 4.74745^{\circ} \mathrm{E}(16)$.

Luciobarbus yahyaouii: FSJF 3331, 10, 75-166 mm SL; Morocco, Mar chica, Small wadi on road to Kariat 
Arkmane, $35.052146^{\circ} \mathrm{N} 2.876565^{\circ} \mathrm{W}$ (32).-FSJF 3313, 19, 67-187 mm SL; Morocco: Oued Za near Guefait, Moulouya, $34.226706^{\circ} \mathrm{N} 2.392343^{\circ} \mathrm{W}(30)$.

Material used for molecular analyses

Barbus barbus. B1, B2, Belgium: Moha prov.: Mehaigne River, Meuse Basin, $50.5451^{\circ} \mathrm{N} 5.1164^{\circ}$ E.River drainage (GenBank accession number: Cyt b: MH187191, MH187192).

Luciobarbus guercifensis. G6, G7, Morocco: Oued Za near Guefait, Moulouya, $34.226706^{\circ} \mathrm{N} 2.392343^{\circ} \mathrm{W}$ (GenBank accession number: Cyt b: MH187189, MH187190; D-loop: MH187212, MH187213).

Materials examined but not preserved (used for osteological study).

Luciobarbus biscarensis: 24, 242-308 mm SL; Algeria: Khenchela prov.: Oued el Arab at Babar, $35.166192^{\circ} \mathrm{N}$ $7.020921^{\circ} \mathrm{E}(41)$.

Luciobarbus callensis: 2, 313-334 mm SL; Algeria: El-Taref prov.: Oued Bou-Namoussa in Seybouse drainage, $36.621504^{\circ} \mathrm{N} 8.057990^{\circ} \mathrm{E}(8) .-19,205-292 \mathrm{~mm}$ SL; Algeria: Guelma prov.: Oued Bouhamdane at Hammam Debagh drainage, $36.468478^{\circ} \mathrm{N} 7.229560^{\circ} \mathrm{E}(9)$.

Luciobarbus chelifensis: 3, 242-262 mm SL; Algeria: Relizane prov.: Oued Rhiou at Sidi Abed village, $36.009889^{\circ} \mathrm{N} 0.992520^{\circ} \mathrm{E}(23) .-6,252-300 \mathrm{~mm}$ SL; Algeria: Relizane prov.: Gagar Dam at Ouled Taieb village, $35.908391^{\circ} \mathrm{N} 1.008624^{\circ} \mathrm{E}(24) .-9,111-165 \mathrm{~mm} \mathrm{SL}$; Algeria: Chelif prov.: Oued Sly west of Ouled Ben Abdelkader village, $36.026609^{\circ} \mathrm{N} 1.266014^{\circ} \mathrm{E}(22) .-1,267 \mathrm{~mm}$ SL; Algeria: Ain Defla prov.: Ghrib reservoir at Oued Chorffa, $36.140553^{\circ} \mathrm{N} 2.563226^{\circ} \mathrm{E}(21)$.

Luciobarbus leptopogon: 21, 82-175 mm SL; Algeria: Blida prov.: Oued Hammam Melouane, $36.4829^{\circ} \mathrm{N}$, $3.0414^{\circ} \mathrm{E}(20)$.

Luciobarbus mascarensis: 15, 67-158 mm SL; Algeria: Algeria: Mascara prov.: Oued Taria north of Meftah Sidi Boubekeur, $35.109848^{\circ} \mathrm{N}, 0.0673^{\circ} \mathrm{E}(26)$.

Luciobarbus lanigarensis: 23, 61-210 mm SL; Morocco: Guenfouda prov.: Oued Isly, $34.5118^{\circ} \mathrm{N} 2.05826^{\circ} \mathrm{W}(29)$.

Luciobarbus numidiensis: 15, 217-430 mm SL; Algeria: Mila prov.: Beni-Haroun reservoir, $36.3319^{\circ} \mathrm{N}, 6.1611^{\circ} \mathrm{E}$ (11).

Luciobarbus setivimensis: 10, 187-363 mm SL; Algeria: Bordj-Bou-Arreridj prov.: Ain Zada Dam at Ain Taghrout, $36.151209^{\circ} \mathrm{N} 5.159443^{\circ} \mathrm{E}(13)$.

\section{Acknowledgements}

We are grateful to Serkan Wesel and Fabian Herder (ZFMK) for their assistance and for allowing us to examine material under their care. Emmanuel Vreven, Miguel Parrent, Tobias Musschoot (RMCA) are thanked for their time and providing pictures. This study is a part of the training session on FishBase and fish taxonomy at RMCA, Tervuren (Belgium). Photographs of some fishes are visible on the digital collections of the RMCA at http:// digit03.africamuseum.be/home. It is publication number BRC 422 of the Biodiversity Research Center, Université Catholique de Louvain, Belgium. This study was supported by the FREDIE project, supported by the Leibniz Association Joint Initiative for Research and Innovation (SAW).

\section{Literature cited}

Bazinet, A.L., Zwikhl, D.J. \& Cummings, M.P. (2014) Agateway for phylogenetic analysis powered by grid computing featuring GARLI 2.0. Systematic Biology, 63, 812-818. https://doi.org/10.1093/sysbio/syu031

Brahimi, A., Freyhof, J., Henrard, A. \& Libois, R. (2017) Luciobarbus mascarensis and Luciobarbus chelifensis (Cyprinidae): two new species in Algeria. Zootaxa, 4277 (1), 32-50. https://doi.org/10.11646/zootaxa.4277.1.3

Casal-Lopez, M., Perea, S., Yahyaoui, A. \& Doadrio, I. (2015) Taxonomic review of the genus Luciobarbus Heckel; 1843 (Actinopterygii, Cyprinidae) from northwestern Morocco with the description of three new species. Graellsia, 71, 1-24 https://doi.org/10.3989/graellsia.2015.v71.135

Clavero, M., Qninba, A., Riesco, M., Esquivias, J., Calzada, J. \& Delibes, M. (2017) Fish in Mo- roccan desert rives: the arid extreme of Mediterranean streams. Fishes in Mediterranean Environments, 003, 1-21. https://doi.org/10.29094/FiSHMED.2017.003 
Doadrio, I., Casal-López, M. \& Perea, S. (2016a) Taxonomic remarks on Barbus moulouyensis Pellegrin, 1924 (Actinopterygii, Cyprinidae) with the description of a new species of Luciobarbus Heckel, 1843 from Morocco. Graellsia, 72, 1-24. https://doi.org/10.3989/graellsia.2016.v72.174

Doadrio, I., Casal-López, L. Perea, S. \& Yahyaoui, A. (2016b) Taxonomy of rheophilic Luciobarbus Heckel, 1842 (Actinopterygii, Cyprinidae) from Morocco with the description of two new species. Graellsia, 72, 1-17. https://doi.org/10.3989/graellsia.2015.v71.135

Felsenstein, J. (1981) Evolutionary tree from DNA sequences, a maximum likelihood approach, Journal of Molecular Evolution, 17, 368-376. https://doi.org/10.1007/BF01734359

Geiger, M.F., Herder, F., Monaghan, M.T., Almada, V., Barbieri, R., Bariche, M., Berrebi, P., Bohlen, J., Casal-Lopez, M., Delmastro, G.B. Denys, G.P., Dettai, A., Doadrio, I., Kalogianni, E., Kärst, H., Kottelat, M., Kovačić, M., Laporte, M., Lorenzoni, M., Marčić, Z., Özuluğ, M., Perdices, A., Perea, S., Persat, H., Porcelotti, S., Puzzi, C., Robalo, J., Šanda, R., Schneider, M., Šlechtová, V., Stoumboudi, M., Walter, S. \& Freyhof, J. (2014) Spatial heterogeneity in the Mediterranean Biodiversity Hotspot affects barcoding accuracy of its freshwater fishes. Molecular Ecology Resources, 14, 1210 -1221. https://doi.org/10.1111/1755-0998.12257

Gouy, M., Guindon, S. \& Gascuel, O. (2010) SeaView Version 4: A multiplatform graphical user interface for sequence alignment and phylogenetic tree building. Molecular Biolology and Evolution, 27, 221-224. https://doi.org/10.1093/molbev/msp259

Hasegawa, M., Kishino, H. \& Yano, T. (1985) Dating of the human-ape split by a molecular clock by michondrial DNA. Journal of Molecular Evolution, 22, 160-174. https://doi.org/10.1007/BF02101694

Iguchi, K., Tanimura, Y. \& Nishida, M. (1997) Sequence divergence in the mtDNA control region of amphidromous and landlocked forms of ayu. Fish Sciences, 63, 901-905. https://doi.org/10.2331/fishsci.63.901

Katoh, K. \& Standley, D.M. (2013) MAFFT Multiple sequence alignment Software Version 7. Improvements in performance and usability. Molecular Biology and Evolution, 30, 772-780. https://doi.org/10.1093/molbev/mst010

Kimura, M. (1980) Estimation of evolutionary distances between homologous nucleotide sequences. Proceedings of the National Academy of Sciences, 78, 454-458. https://doi.org/10.1073/pnas.78.1.454

Kottelat, M. \& Freyhof, J. (2007). Handbook of European Freshwater Fishes. Cornol, Suisse, xiv + 646 pp.

Lanave, C., Preparata, G., Saccone, C. \& Serio, G. (1984) A new method for calculating evolutionary substitution rates. Journal of Molecular Evolution, 20, 86-93. https://doi.org/10.1007/BF02101990

Lanfear, R., Frandsen, P.B., Wright, A.M., Senfeld, T. \& Calcott, B. (2017) PartitionFinder 2: new methods for selecting partitioned models of evolution for molecular and morphological phylogenetic analyses. Molecular Biolology and Evolution, 34, 772-773.

https://doi.org/10.1093/molbev/msw260

Nishida, M., Ohkawa, T. \& Iwata, H. (1998) Methods of analysis of genetic population structure with mitochondrial DNA markers. Fish Genetics and Breeding Science, 26, 81-100. https://doi.org/10.1371/journal.pone.0179706

Palumbi, S.R. (1996) Nucleic acids II: The polymerase chain reaction. In: Hillis, D.M., Moritz, C. \& Mable, B.K. (Eds.), Molecular Systematic. $2^{\text {nd }}$ Edition. Sinauer, Sunderland, MA, pp. 5-247.

Perdices, A. \& Doadrio, I. (2001) The molecular systematics and biogeography of the European cobitids based on mitochondrial DNA sequences. Molecular Phylogenetics and Evolution, 19, 468-478. https://doi.org/10.1006/mpev.2000.0900

Rambaut, A. (2009) FigTree. Version 1.4.2. Available from: http://tree.bio.ed.ac.uk/software/figtree/ (accessed 2 May 2017)

Rodríguez, F., Oliver, J.L., Marín, A. \& Medina, J.R. (1990) The general stochastic model of nucleotide substitution. Journal of Theoretical Biology, 142 (4), 485-501. https://doi.org/10.1016/S0022-5193(05)80104-3

Ronquist. F., Teslenko, M., Mark, P., Ayres, D.L., Darling, A., Höhna, S., Larget, B., Liu, L., Suchard, M.A. \& Huelsenbeck, J.P. (2012) MrBayes 3.2. Efficient Bayesian phylogenetic inference and model choice across a large, model space. Systematic Biology, 61, 539-542. https://doi.org/10.1093/sysbio/sys029

Sukumaran, J. \& Holder, M.T. (2010) DendroPy, a Python library for phylogenetic computing. Bioinformatics, 26, $1569-1571$. https://doi.org/10.1093/bioinformatics/btq228

Sukumaran, J. \& Holder, M.T. (2015) SumTrees. Phylogenetic tree Summarization, 4.0.0 Available from: https://github.com/ jeetsukumaran/Dendrophy (accessed 2 May 2017)

Talavera, G. \& Castresana, J. (2007) Improvement of phylogenies after removing divergent and ambiguously aligned blocks from protein sequence alignments. Systematic Biology, 56, 564-577.

https://doi.org/10.1080/10635150701472164 
Tamura, K., Stecher, G., Peterson, D., Filipski, A. \& Kumar, S. (2013) Molecular Evolutionary Genetics Analysis: MEGA version 6.0. Molecular Biology and Evolution 30, 2725-2729. https://doi.org/10.1093/molbev/mst197

Tavaré, S. (1986) Some probabilistic and statistical problems in the analysis of DNA sequences. Lectures on Mathematics in the Life Sciences (American Mathematical Society), 17, 5786. 